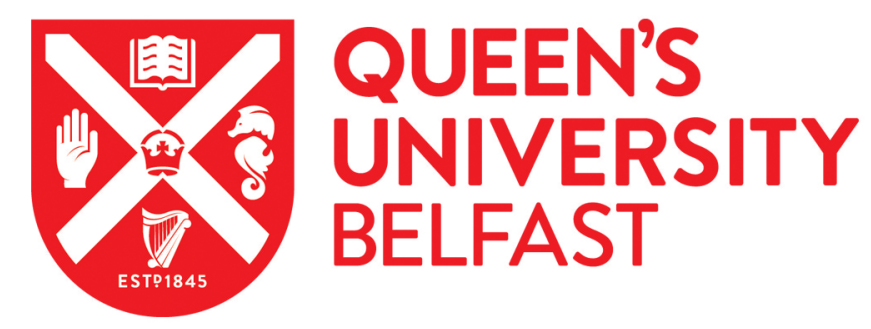

\title{
Law, Politics and Financial Development: The Great Reversal of the U.K. Corporate Debt Market
}

Coyle, C., \& Turner, J. D. (2013). Law, Politics and Financial Development: The Great Reversal of the U.K. Corporate Debt Market. The Journal of Economic History, 73(3), 810-846.

https://doi.org/10.1017/S0022050713000624

\section{Published in:}

The Journal of Economic History

Document Version:

Early version, also known as pre-print

Queen's University Belfast - Research Portal:

Link to publication record in Queen's University Belfast Research Portal

\section{General rights}

Copyright for the publications made accessible via the Queen's University Belfast Research Portal is retained by the author(s) and / or other copyright owners and it is a condition of accessing these publications that users recognise and abide by the legal requirements associated with these rights.

Take down policy

The Research Portal is Queen's institutional repository that provides access to Queen's research output. Every effort has been made to ensure that content in the Research Portal does not infringe any person's rights, or applicable UK laws. If you discover content in the Research Portal that you believe breaches copyright or violates any law, please contact openaccess@qub.ac.uk. 


\title{
Law, Politics, and Financial Development: The Great Reversal of the U.K. Corporate Debt Market
}

\author{
CHRISTOPHER COYLE AND JOHN D. TURNER
}

This article examines the role of creditor protection in the development of the U.K. corporate bond market. This market grew rapidly in the late nineteenth century, but in the twentieth century it experienced a reversal, albeit with a short-lived post-1945 renaissance. Such was the extent of the reversal that the market from the 1970s onwards was smaller than it had been in 1870 . We find that law does not explain the variation in the size of this market over time. Alternatively, our evidence suggests that inflation and taxation policies were major drivers of this market in the post-1945 era.

F inancial development usually occurs if the "correct" set of institutions and laws are in place. The legal origins theory argues that these are largely determined by a country's legal family (Beck, Demirgüç-Kunt, and Levine 2003; La Porta et al. 1997, 1998, 2000; La Porta, Lopez-De-Silanes, and Shleifer 2008; Levine 1999). Political economy theories, on the other hand, argue that the institutions in place will largely be determined by a country's political system, which can be influenced by exogenous shocks such as wars or changes in openness to trade (Rajan and Zingales 2003; Roe 2006; Perotti and Von Thadden 2006; Roe and Siegel 2009). In this article, we examine the evolution of the U.K. domestic corporate debt market from its inception in the middle of the nineteenth century until the twenty-first century in an attempt to understand the role played by law in the development of financial markets.

Using annual data for the period 1860-2002, we find that after nearly 50 years of growth from 1860 onwards, the U.K. corporate bond market experienced a great reversal in the twentieth century.

The Journal of Economic History, Vol. 73, No. 3 (September 2013). (C) The Economic History Association. All rights reserved. doi: 10.1017/S0022050713000624.

Christopher Coyle is Lecturer in Finance and John D. Turner is Professor of Finance and Financial History, Queen's University Management School, Queen's University of Belfast, Belfast BT7 1NN, Northern Ireland, UK. E-mails: c.coyle@qub.ac.uk and j.turner@qub.ac.uk.

An earlier version of this article was presented at QUCEH workshops at Queen's University Belfast, the Fourth EuroStock History conference in Bonn, and the 2012 European Business History Association conference in Paris. Thanks to Graeme Acheson, John Armour, Gerben Bakker, Stefano Battilossi, Matthias Beck, Mark Billings, Graham Brownlow, Carsten Burhop, Gareth Campbell, David Chambers, Brian Cheffins, Chris Colvin, Marc Deloof, Les Hannah, Joost Jonker, Gerhard Kling, David Le Bris, Amir Rezaee, Janette Rutterford, Luke Samy, and Steve Toms for their comments. Coyle acknowledges financial support from the Department of Education and Learning. 
After a post-1945 renaissance, the U.K. corporate bond market went into permanent decline in the 1970s. The collapse of this market in the 1970s meant that it was smaller in real terms than it had been in the 1870s. In terms of the number of traded corporate bonds, the U.K. corporate bond market was smaller in the 1990s than it had been a century earlier.

The proponents of the law and finance hypothesis argue that legal origin and investor protection laws determine financial development (La Porta et al. 1997, 1998; La Porta, Lopez-De-Silanes, and Shleifer 2008). However, despite its historical nature, most of the tests of this hypothesis have been cross-sectional and ahistorical in nature. ${ }^{1}$ One notable exception is Aldo Musacchio (2008a, 2010) who finds little evidence to support the law and finance hypothesis and suggests that to comprehend the variation in modern financial development, we need to understand the effect of the catastrophic events of the twentieth century. ${ }^{2}$ In this article, we examine changes in U.K. creditor protection from 1860 to 2002 to see if it is driving the development of the U.K. corporate bond market. As such, this is one of the first long-run times series tests of the law and finance hypothesis. ${ }^{3}$ As the creditor protection score remains high (at four out of four) for the United Kingdom over this entire period, it cannot possibly explain the variation over time in the size of the bond market.

Given that law does not explain the variation in bond market size over time, in this article we also explore what was driving the development of the bond market, particularly its post-1945 renaissance and its post1970 demise. We have two hypotheses: (a) inflation explains the post-1970 demise of the U.K. bond market, and (b) tax changes which affected the capital structure preferences of firms explain the post1945 renaissance of the market. The demise that preceded the postwar renaissance was mainly due to the nationalization of many large companies which issued bonds. Using data on bond returns and issues,

\footnotetext{
${ }^{1}$ Djankov, McLeish, and Shleifer (2007) use an event-study approach to examine the effect of changes in creditor rights on private credit across 129 countries, but the law and finance literature does not examine long-run time-series evidence on financial development.

${ }^{2}$ Cheffins, Bank, and Wells (2012) look at the interaction of U.S. shareholder protection laws and stock market development over the period 1930-1970. Armour et al., (2009) and Sarkar and Singh (2010) use a longitudinal shareholder protection index covering United Kingdom, United States, Germany, France, and India for 1970-2005 to examine the relationship between financial development and investor protection. Notably, all of these papers find evidence which rejects the law and finance hypothesis.

${ }^{3}$ There are two studies related to our article which also look at the long-run development of financial markets. Franks, Mayer, and Rossi (2009) argue that law did not affect the evolution of corporate ownership in the United Kingdom over the twentieth century. Biais and Green (2007) find that the migration of bonds from the New York Stock Exchange to OTC markets in the twentieth century can be explained by the rise of institutional investors.
} 
we find that inflation plays a major part in the demise of the U.K. corporate bond market. In addition, our evidence reveals that companies took advantage of the increased tax shield in the post-1945 era by issuing more bonds. Inflation and tax changes, however, are only proximate causes of changes in the U.K. bond market, since they reflect broader macroeconomic policy goals.

Richard S. Grossman (2002, p. 128) has suggested that the growth of the corporate bond market in late Victorian Britain is an important agenda requiring further research. Our article not only measures the growth of the corporate bond market in the Victorian period by providing annual estimates of its size and performance, but we also place this initial growth in the context of its long-term twentieth-century demise. Although the historiography of British capital markets has discussed the use of corporate bonds by nineteenth-century companies (Jefferys 1977, pp. 241-92), institutional and individual investors in debentures (Raynes 1928; Sheppard 1971, pp. 154-56; Scott 2002; Maltby et al. 2011; Michie 2011, p. 163; Rutterford et al. 2011), and the interwar issuance of debt (Grant 1967, p. 166; Thomas 1978, p. 36; Chambers 2010 , p. 57), there have been no studies which have examined the size, performance, and drivers of the market over the long run. In terms of the performance of the corporate bond market, K. C. Smith and G. F. Horne (1934) as well as Edelstein $(1976,2010)$ assess the returns on a limited number of high-class corporate bonds for 1867-1933 and 18701913 respectively. ${ }^{4}$ In contrast, our examination of performance looks at the nearly all traded corporate bonds from 1860 to 2002. Apart from Musacchio (2010), who has developed several point estimates for the early twentieth century, we know of no other attempt to assess the size of the U.K. domestic corporate bond market over the long run.

This article augments the small but growing literature which examines the effect of legal protection and origins on financial development from an historical perspective. ${ }^{5}$ As with the vast majority of this literature, this article finds little evidence to support the law and finance hypothesis. ${ }^{6}$

\footnotetext{
${ }^{4}$ Smith and Horne's index of fixed interest securities for 1867-1933 includes Consols, bonds of municipal authorities, as well as London and North-Western railway debentures. Edelstein's study of realized returns on U.K. and overseas investments contains 65 domestic debentures in 1910, whereas our series of returns contains 422 debentures in that year. Raynes $(1928,1937)$ provides figures on the annual income generated between 1912 and 1936 by a small number of debentures of blue-chip companies.

${ }^{5}$ See, for example, Cheffins (2001); Campbell and Turner (2011); Fohlin (2007); Guinnane et al. (2007); Lamoreaux and Rosenthal (2005); Malmendier (2009); Musacchio (2008b, 2009, 2010); Roe (2006).

${ }^{6}$ One exception is Bordo and Rousseau (2006), but their measure of financial development (ratio broad money to GDP) is more a measure of banking rather than financial market development.
} 
The findings of our article may also have some bearing on the extensive literature on whether banks failed British industry. ${ }^{7}$ Notably, we show that when the bond market contracted in the 1970s, recently liberalized banks, which were no longer constrained by government policy regarding their lending, met the high demand from companies for debt finance. This article also contributes to the growing literature which examines returns on U.K. financial assets over the long run by adding another asset class to aid our understanding of asset pricing in the long run. ${ }^{8}$

\section{THE U.K. CORPORATE BOND MARKET, 1860-2002}

The traditional U.K. appellation for corporate bond, as well as bonds issued by municipal authorities and government-controlled entities, is debenture. ${ }^{9}$ Debentures include any long-term debt secured on the assets of the company. ${ }^{10}$ Our study commences in 1860 when an active debenture market first arose in the United Kingdom (Jefferys 1977, pp. $241-51) .^{11}$

As we are interested in the size and performance of the domestic corporate bond market, we collected data on debentures issued by U.K. companies. We excluded all financial companies that issued debentures from our data set as these firms were mainly financial trusts which issued debentures with the aim of investing the bulk of the proceeds in the equities and debentures of foreign companies (Jefferys 1977, p. 262).

A company was considered to be a U.K. company if its corporate headquarters and the main market where its securities traded were in the United Kingdom and its main activities were based in the United Kingdom. ${ }^{12}$ This information was obtained from a combination of the Investor's Monthly Manual (1864-1930); Burdett's Official

\footnotetext{
${ }^{7}$ See, for example, Baker and Collins (1999); Capie and Collins (1992); Collins (1990, 1991); Collins and Baker (2001, 2003); Kennedy (1987).

${ }^{8}$ See Acheson et al. (2009); Grossman (2002); Dimson, Marsh, and Staunton (2002).

${ }^{9}$ Technically, debentures which are traded on public markets are known as debenture stocks (Simonson 1920, pp. 4-6).

${ }^{10}$ A charge on the company's assets was not always implied by the use of the word debenture (Manson 1894, p. 35), but over time the word debenture in the United Kingdom has come to mean secured debt.

${ }^{11}$ For example, railway debentures are not quoted in the Course of the Exchange until 1860.

${ }^{12}$ The criteria used to determine whether a company was located in the United Kingdom or overseas was based on the (a) the section in which it appears in the relevant stock exchange yearbook (e.g., Foreign Railways), (b) the company's name (e.g., New Zealand and Australia Land Co., Ltd.), or (c) if the company had a head office in a foreign country of operation as well as one in the United Kingdom.
} 
Intelligence (1882-1898), the Stock Exchange Official Intelligence (1899-1933), and the Stock Exchange Yearbook (1934-2002).

In order to estimate the annual size, value, and performance of the debenture market, we gathered data on debenture coupon rates, the number of outstanding debenture stocks, the nominal value of debentures (which was usually £100), and debenture prices (which were based on transactions at which business was done) on the last day of December. ${ }^{13}$

Our data was obtained from three main sources. First, debenture data for the period 1860-1863 was hand collected from the Course of the Exchange (COE). Second, data for the period 1864-1929 was culled from the Investor's Monthly Manual (IMM). As we shall see below, the change in sources had no effect on the number of debentures in the sample.

For the remainder of the sample period, we relied on the Stock Exchange Daily Official List (SEDOL); hard copies of which are available at the Guildhall Library in London for the period 1930-2002. Unlike the $I M M$, by 1930 SEDOL contains a comprehensive list of all securities (no matter how minor) traded in the United Kingdom's various stock exchanges. ${ }^{14}$ As we will see below, its comprehensive nature results in a jump in the number of corporate bonds in 1930, whenever our data sources change. However, most of these additional debentures are very small issues as the total value of debentures changes relatively little between 1929 and $1930 .^{15}$ As the post-1946 copies of SEDOL do not contain the capital outstanding for each debenture issue, we collected this data at decadal intervals from the Stock Exchange Yearbook.

A key issue in this study is that debenture securities are correctly identified in our three data sources. The $C O E$ had a separate section for railway debentures and debentures in other sectors were clearly labeled as such. In the cases of the $I M M$ and $S E D O L$, we only collected data where "deb" or "debenture" was tagged alongside or below the company's name.

\footnotetext{
${ }^{13}$ On the rare occasions when an end-of-year price was unavailable, the last price available or the midpoint of the bid-ask spread (this was only available from 1930 onwards in our data sources) was used. As the London Stock Exchange was closed for five months at the end of 1914, we use the price from 30th July 1914 as the end-of-year price.

${ }^{14}$ There was no OTC market in the United Kingdom for corporate bonds and equities for most of our sample period. After the stock market reforms of 1986, an OTC market developed, and SEDOL contains securities traded on this market.

${ }^{15}$ The total value of debentures increased 9 percent between 1929 and 1930. However, the value of the debenture market increased by an average of 7 percent each year between 1860 and 1946.
} 
The point estimates developed by A. Essex-Crosby (1938) for 1885, 1895 , and 1915 report a substantially higher figure for the total value of the debenture market than we find. ${ }^{16}$ Essex-Crosby uses Burdett's Official Intelligence (BOI) to develop his estimates of the size of the U.K. debenture market. Apart from the fact that we exclude financial companies, there are two reasons for this difference. First, we exclude foreign companies. Second, it was common for many companies at this time to have debentures which were not publicly issued and were not traded on markets (Jefferys 1977, p. 286). ${ }^{17}$ For example, the par value of our brewery debentures in 1895 is $£ 17.4$ million, whereas the total par value of brewery debentures in Burdett's Official Intelligence in 1895 is $£ 33.8$ million. Debentures issued by foreign companies account for $£ 8.9$ million of this difference and debentures which are not publicly traded accounts for another $£ 7.3$ million.

Figures 1 and 2 (as well as Appendix Table 1) show the development of the U.K. debenture market in terms of number and par value of debentures. The most remarkable finding is that the U.K. debenture market has experienced a Rajan-and-Zingales-type great reversal, with the number of debentures and the real par value of debentures at the end of the twentieth century below their levels in 1870 and 1894 respectively.

The debenture market grew rapidly in its first four decades. Up until the late 1880 s, at least 75 percent of debentures were issued by railways (Appendix Table 1), and railways dominated in terms of par value. ${ }^{18}$ During the 1870 s, however, small debenture issues were made by gas companies, iron, coal and steel companies, and commercial/industrial companies. In the case of the latter two sectors, preexisting firms converted to public limited companies, and viewed debentures as a way of raising additional capital (Jefferys 1977, p. 252). As can be seen from Appendix Table 1, from the late 1880s until just before 1913, there was a significant increase in the number and value of non-railway debentures. This growth came mainly from debentures issued by breweries and commercial/industrial companies (see Appendix Table 1). ${ }^{19}$

\footnotetext{
${ }^{16}$ The figures can be found in Jefferys (1977, pp. 458-60).

${ }^{17}$ Private debentures appear to be a pre-1913 phenomenon as there is little evidence in stock exchange manuals of them being used after 1913

${ }^{18}$ Railway debentures played an important role in familiarizing investors with corporate bonds (Jefferys 1977, p. 246).

${ }^{19}$ See Watson (1996), Jefferys (1977, p. 268) and Cottrell (1980, p. 168) on the conversion of the breweries and their widespread use of debentures.
} 


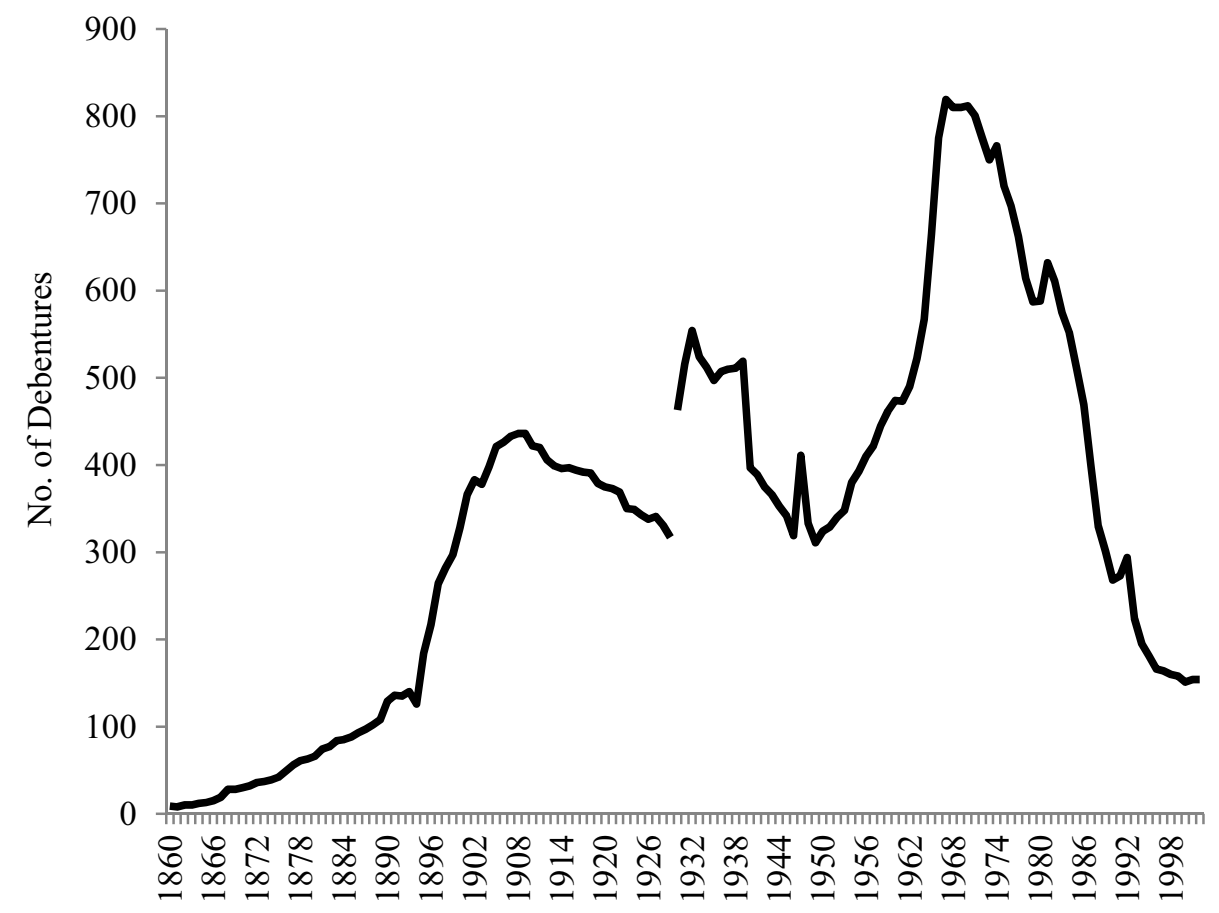

FIGURE 1

NUMBER OF DOMESTIC DEBENTURES TRADED ON U.K. STOCK EXCHANGES, 1860-2002

Notes: The series is broken between 1929 and 1930 due to a change in our data sources.

Sources: Course of the Exchange (1860-1863); Investor's Monthly Manual (1864-1929); Stock Exchange Daily Official List (1930-2002).

The debenture market reached its peak in 1909 (as measured by total par value in real terms). Railway debentures constituted 63.5 percent of total par value. Indeed, debentures were so popular that new businesses going public often issued debentures and equity in the proportion of one-third to two-thirds (Jefferys 1977, pp. 270-72, 458-60). At its peak in 1909, the par value of debentures was 22 percent of GDP, but by 1919 it had fallen to just below 8 percent of GDP (Figure 2), following the high inflation during of World War I. The market staged something of a recovery between 1920 and 1939, with new debenture issues by brewing, commercial, and industrial companies in the early 1930s. Although our data series for the number of debentures (Figure 1) is affected by the change in data sources in 1930, the downward trend in debenture issues from 1909 to 1946 is still noticeable, despite a series 


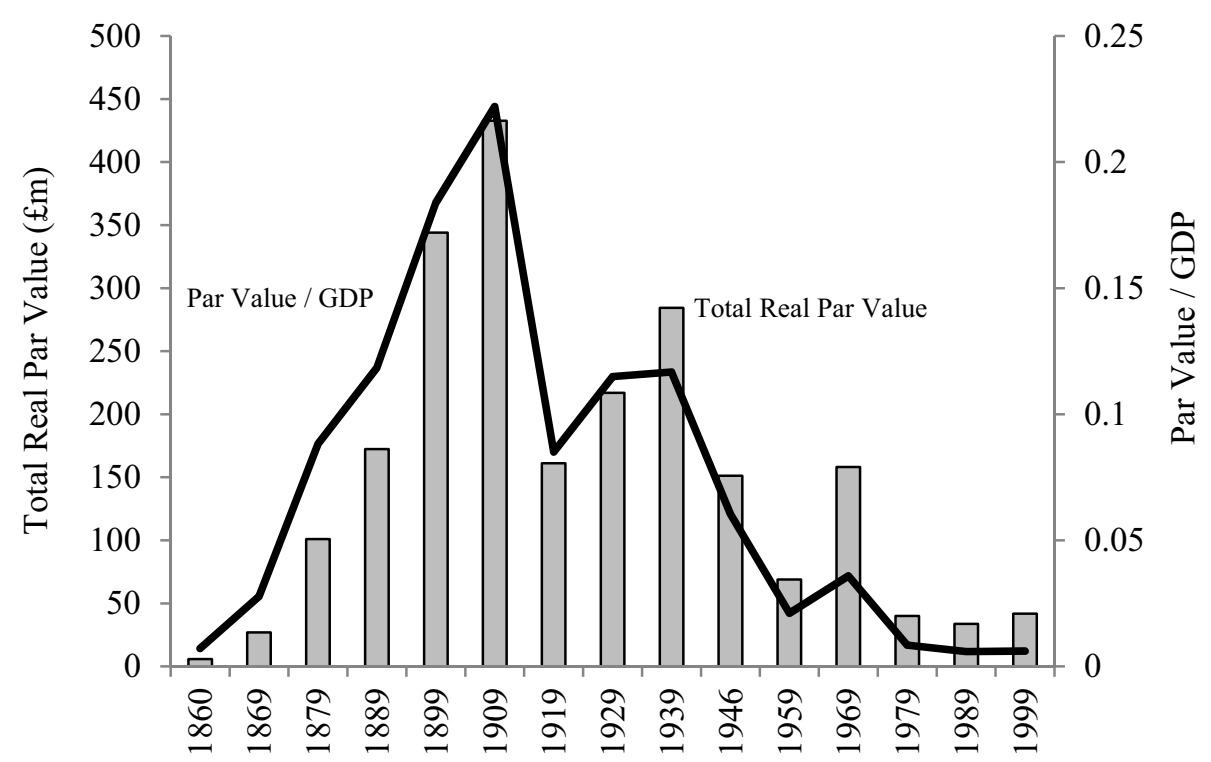

FIGURE 2

VALUE OF DOMESTIC DEBENTURES TRADED ON U.K. STOCK EXCHANGES, 1860-1999

Sources: Course of the Exchange (1860-1863); Investor's Monthly Manual (1864-1929); Stock Exchange Daily Official List (1930-1999); Stock Exchange Official Yearbook (1959-1999). GDP data is from Officer (2011). O'Donoghue, Goulding, and Allen (2004) is used to convert the nominal value into real terms.

of new debenture issues in the early 1930 s. ${ }^{20}$ From 1909 until 1929 six debentures disappeared annually on average, and between 1939 and 1946 the number of debentures declined from 519 to $319 .^{21}$

As Figure 1 shows, the debenture market rebounded after 1946. The number of debentures on the market in the 1960s reached its all-time peak. ${ }^{22}$ Despite the increase in the number of different bonds, their par value fell between 1946 and 1959 (Figure 2). This is largely explained by the fact that 70 percent of the total par value of debentures in 1946 belonged to companies that would be nationalized within a matter of months. In addition, the companies which issued debentures in the two decades after 1946 were commercial or industrial

\footnotetext{
${ }^{20}$ New debenture issues were just less than or exceeded new equity issues from 1930 to 1933 (Grant 1967, p. 166).

${ }^{21}$ A large number of the debentures disappeared in the 1920s due to the governmentorchestrated mergers of the large railway companies following the Railway Act of 1921.

${ }^{22}$ As can be seen from Appendix Table 1, the number of debentures increased substantially in 1947. The immediate reversal of this increase in 1948 was due to the nationalization of railways, gas, and electric lighting and power companies.
} 
companies (i.e., electronics, textiles, television, chemicals, plastics, automobiles, and aircraft), which did not have the same capital needs as those companies which had been nationalized.

One estimate puts debentures share of company borrowing in 1965-1969 at 42.5 percent, ${ }^{23}$ another suggests that from 1963 to 1972 , 15 percent of external funds raised by industrial and commercial companies came from debenture issues (Wilson Committee 1980, p. 51). As can be seen from Figure 1, the debenture market began a rapid decline after 1970, such that by the late 1990s, the market was smaller than it had been a century earlier. In terms of its value (in real terms), the collapse of the market in the 1970s meant that for the rest of the century, the debenture market was smaller than it had been in $1870 .^{24}$ The swift demise of the debenture market resulted in commentators suggesting in the early 1980s that the market was "virtually dead." 25 Figure 3, which shows the value of the debenture market relative to the total market value of domestic corporate securities, reveals that the debenture market was a relatively important part of the U.K. domestic capital market up until 1913. However, after World War II, the debenture market, despite its brief revival in the 1960s, was a small part of the action.

In terms of other corporate bond markets, in 1913, the U.K. domestic market was large; only the United States, France, and Spain had larger bond markets relative to GDP, but the difference was slight

\footnotetext{
23 “Three Proposals for Britain's Budget on March 9th," The Economist, Feb. 27th 1982, p. 13.

${ }^{24}$ During the 1950s and 1960s growing amounts of debt capital were raised through the issue of short-term, unsecured loan stocks. These securities were initially used by companies involved in North Sea oil exploration (Thomas 1978, p. 153), and during the 1960s they were used to finance takeover bids ("Loan Stock for Takeover Bidders," The Times, December 24th 1968). During the 1960s convertible loan stock became increasingly common (Samuels and Wilkes 1975, p. 79). Although the number of loan stocks (convertible or otherwise) listed on SEDOL increased from 15 in 1950 to just over 600 in 1970, they accounted for just a small portion of the stock of fixed interest securities (Thomas 1978, p. 156). As with debentures, the use of this debt instrument reversed sharply from the 1970s onwards, with just over 60 loan stocks listed in 2002.

25 "Resurrecting the Corporate Bond," The Times, July 1st 1981. See the following for further press coverage of the moribund state of the market in this period: "Inflation: Now for the Hard Bit," The Economist, May 29th 1982, p. 36; "Corporate Treasurers in Bondage," The Economist, Aug. 28th 1982; "Debentures on the Horizon," The Times, Oct. 3rd 1977; "A Ripple in the Debenture Market," The Times, Oct. 13th 1977; "Long-Term Corporate Bonds May Return," The Times, Mar. 30th 1981; "Debentures Set For Revival," The Times Aug. 23rd 1982. There were some attempts to issue unsecured long-term bonds at this time, but this market never developed. See, for example, "Industrial Group Moves to Lessen Short-Term Debt," The Times Sept. 10th 1982.
} 


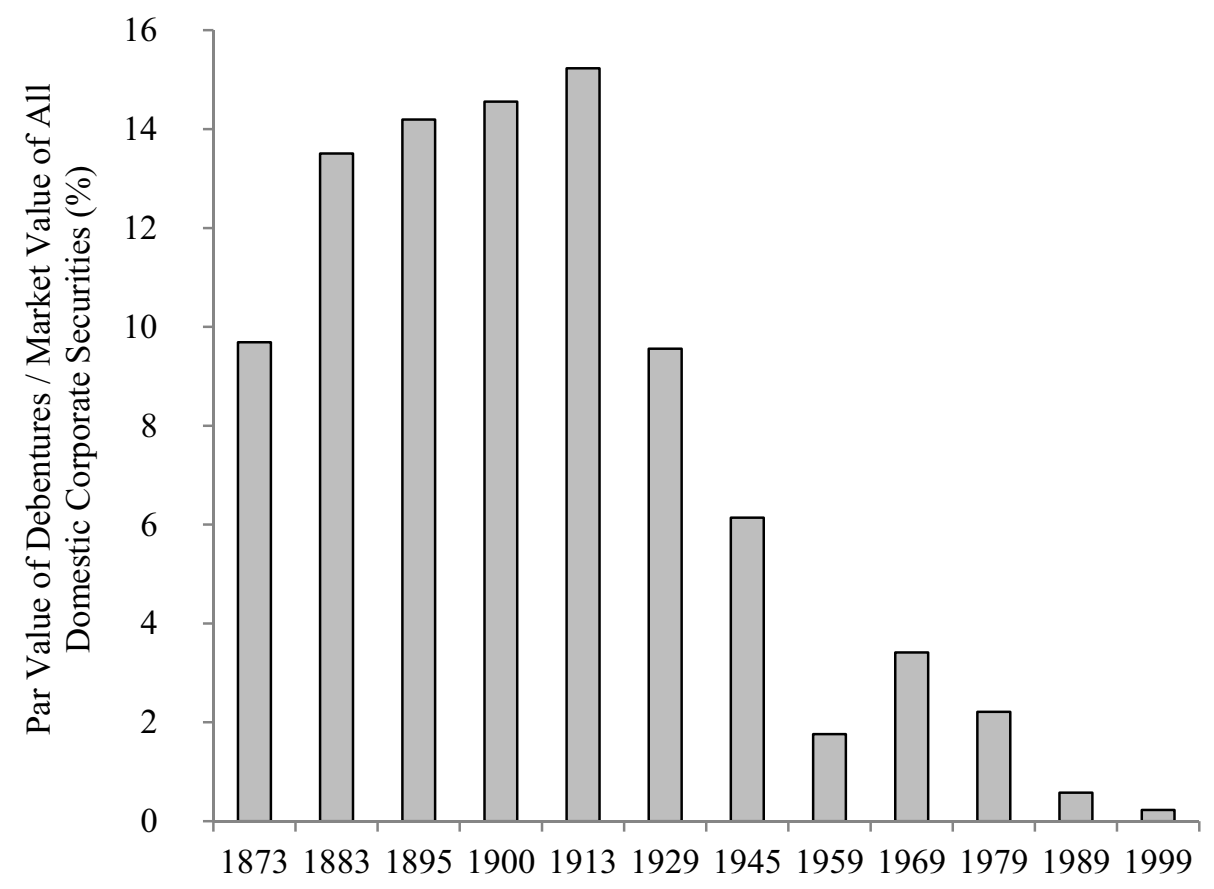

\section{FIGURE 3 \\ VALUE OF DEBENTURES RELATIVE TO TOTAL VALUE OF ALL DOMESTIC CORPORATE SECURITIES, 1873-1999}

Notes: We use Michie's figure for 1960 as an estimate for 1959. The total market data for $1873,1883,1945$, and 1959 may include some non-domestic companies, but these are unlikely to have much bearing on the estimates.

Sources: Debenture data is from Investor's Monthly Manual (1873-1929), Stock Exchange Daily Official List (1945-1999), and Stock Exchange Official Yearbook (1959-1999). We use the nominal values of domestic corporate securities in Morgan and Thomas, Stock Exchange (pp. 280-81) as proxies for market value in 1873 and 1883. The market value of total domestic corporate securities for $1895,1900,1913$, and 1929 is from Musacchio (2010, p. 51). The figures for 1945 and 1959 are from Michie (1999, pp. 360, 440). The figures for 1969-1999 are from the London Stock Exchange (2011).

(Musacchio 2010, p. 58). However, nearly one hundred years later, the U.K. corporate bond market is one of the smallest relative to GDP at 36th amongst the 44 most advanced economies $2011 .^{26}$

\footnotetext{
${ }^{26}$ These figures are based on Bank for International Settlements (BIS) figures on domestic debt securities issued by corporations (Bank for International Settlements, BIS Quarterly Review, p. A115). The BIS figures do not distinguish between short-term and long-dated corporate bonds. The GDP figures were obtained from the World Bank (http://data.worldbank.org/indicator).
} 


\section{LAW AND THE U.K. CORPORATE BOND MARKET}

The "law and finance" hypothesis suggests that creditor protection is associated with better developed debt markets (La Porta et al. 1997, 1998, 2000; La Porta, Lopez-De-Silanes, and Shleifer 2008, p. 294; Djankov et al. 2008). More controversially, however, its proponents also claim that legal origin matters for the strength of these laws, with common law countries having superior protection to civil law countries. Therefore, the United Kingdom (more precisely England), as the home of the common law, is an interesting case study on the evolution of creditor protection law and its relationship to the development of the market for corporate debt.

In the construction of their creditor rights index, there are four rights deemed important by La Porta et al.- no automatic stay on assets, secured creditors get paid first, creditors approve reorganization, and management does not stay during reorganization (La Port et al. 1998, p. 1124). ${ }^{27}$ According to La Porta et al. (1998), the law on the books in 1995 meant that creditors in the United Kingdom had all four of these rights. We examine the evolution of company legislation from the middle of the nineteenth century onwards to see which creditor rights applied over the period 1860 to 2002. Company legislation in the U.K. governed the establishment and operation of U.K. companies and established the rights of creditors as well as shareholders vis-à-vis the company and its management. The Company Clauses Consolidation Act (1845) and the Company Clauses Act (1863) governed the activities of railways and other public utility companies, whilst the Companies Acts from 1862 onwards governed the activities of most other companies. What these acts reveal is that creditors had the four rights deemed important by La Porta et al. (1998) throughout our entire sample period.

The legal origins theory posits that common law countries have better investor protection, and better developed markets. However, as we established above, the market for corporate bonds started contracting after 1913, and essentially became irrelevant after the 1970s, despite a substantial renaissance in the 1950s and 1960s. All this variation occurred without any change in the United Kingdom's creditor protection score. Something other than statute law was driving bond market development over the long run.

\footnotetext{
${ }^{27}$ Although the so-called "London Approach" may offer an informal manager-friendly substitute to the debtor-friendly law on the books, it is a far cry from a manager-driven bankruptcy process (Armour, Cheffins, and Skeel 2002, pp. 1757-60; Brierly and Vlieghe 1999).
} 
In fact, the law and finance literature perhaps overemphasizes the importance of statutory investor protection law in common law countries. In the case of the United Kingdom, there were legal innovations that came from case law that perhaps help us understand the initial takeoff of the bond market. Sometime during the 1860s, English lawyers began drafting contracts with a floating charge, which was where a creditor was granted security against all present and future assets, but was prevented from interfering with the operations of the firm until it officially entered bankruptcy (Armour, Cheffins, and Skeel 2002, p. 1739; Finnie 1931, p. 45). When a firm officially entered the bankruptcy process, the holders of the floating charge debentures had a claim on all the assets of the firm. The floating charge was initially slow to obtain judicial recognition (Pennington 1960, p. 642), but in a series of cases, the validity of the floating charge was upheld. ${ }^{28}$ The innovation of the floating charge and the legal validity it acquired in the 1870s resulted in the widespread use of debentures by all types of companies (Simonson 1920, p. 26; Jefferys 1977, p. 273). ${ }^{29}$

The law and finance school of thought could perhaps argue that the role of the judiciary in supporting the development of the floating charge is perhaps a testament to the common-law way of doing things - judges resolving contractual disputes, responding dynamically to a new business environment, and creating precedents that enabled future, similar contracts to be made on a firmer basis. ${ }^{30}$ However, the doctrine of the floating charge comes from equity not common law principles, and the cases in the 1870s where judges underpinned the validity of the floating charge were heard in the Chancery Court not the common law courts (Curtis 1941, p. 131; Pennington 1960, p. 630).

\section{EXPLAINING VARIATION OF BOND MARKET OVER TIME}

The U.K. corporate bond market experienced a great reversal in the twentieth century, albeit with a brief but substantial renaissance in

\footnotetext{
${ }^{28}$ In Re Panama, New Zealand and Australian Royal Mail Co. (1870), LR 5 Ch App 318, the judge ruled that the word "undertaking" in the company's 1866 debenture contract covered all the company's assets at the point of bankruptcy. Re Florence Land Co. (1878), 10 Ch D 530; Re Colonial Trusts (1879), 15 Ch D 465; Re Henry Pound (1889), 42 Ch D 402. See Pennington (1960, p. 630) and "The Debentures of Limited Companies," The Economist, Jan. 16th1886, p. 67 , which discusses the frequency with which cases on floating charges came before the courts.

${ }^{29}$ The ubiquity of the floating charge was such that a 1906 Parliamentary Committee stated that it was almost universally used by companies issuing debentures, and in many cases, the floating charge was practically the only security which could be issued (Parliamentary Papers 1906, pp. 14-15).

${ }^{30}$ On this point, see Beck, Demirgüç-Kunt, and Levine (2003) and La Porta et al. (2000, pp. 9, 12).
} 
the 1950s and 1960s. As established above, structural theories about legal origin and creditor protection cannot explain this phenomenon. Raghuram Rajan and Luigi Zingales (2003) argue that financial markets contracted during the 1930-1970 period due to incumbent opposition to financial development, which thrived thanks to reduced openness to trade and capital flows. The subsequent recovery of financial markets after the collapse of the Bretton Woods agreement is largely due to the fact that increased capital flows and trade openness undermined incumbent opposition to financial development. However, the development of the U.K. corporate bond market in the twentieth century does not quite fit with this theory. First, the corporate bond market did not contract in the post-1945 period-indeed it expanded rapidly in the 1950s and 1960s. Second, the corporate bond market shriveled up after cross-border trade and capital flows were liberalized after 1970. Consequently, in the rest of this section, we test two hypotheses about what drove U.K. corporate bond markets in the twentieth century. In the first hypothesis, we analyze whether inflation can explain the demise of the U.K. bond market. In the second hypothesis, we examine the role of tax changes on the capital structure preferences of firms to see whether this explains its renaissance in the 1950s and 1960s.

\section{Inflation}

There is a well-documented negative relationship between inflation and financial market activity (Huybens and Smith 1999; Boyd, Levine, and Smith 2001). Enrico Perotti and Ernst-Ludwig von Thadden (2006), Perotti and Armin Schwienbacher (2009) and Mark Roe and Jordan Seigel $(2009,2011)$ go further and argue that inflation partially explains the evolution of and variation across financial markets in the twentieth century. Specifically, Musacchio (2008a) finds that inflation was an important post-1914 driver of corporate bond market size in Brazil. Consequently, we hypothesize that inflation was important to the U.K. corporate bond market, particularly after the devaluation of sterling in 1967.

In order to examine the effect of inflation on the corporate bond market, we calculated yearly nominal total log returns for each debenture by combining coupon payments with the change in the debenture price over the year. ${ }^{31}$ These returns were then used to calculate unweighted

\footnotetext{
${ }^{31}$ Overall, there are 48,493 price observations in the sample.
} 
annual average returns. ${ }^{32}$ Nominal returns were converted into real returns using inflation data published by the Office of National Statistics (O'Donoghue et al. 2004). When aggregating returns, one also needs to take into account the debentures of failed companies, with the result that the investor could potentially lose some of their initial investment. We checked every delisted debenture against the Register of Defunct Companies, which lists the fate of companies that delisted from the stock exchange from 1875 onwards as well as the payment received by equity and debenture holders if the company was liquidated. ${ }^{33}$ Remarkably, over the whole sample period, only in 13 cases of delisting did debentureholders lose any capital. This fact underscores the "legendary security" of debentures, which made them very popular with investors (Jefferys 1977, p. 280). As the Register of Defunct Companies usually states the amount paid back to debenture holders, the returns for that debenture were adjusted accordingly. ${ }^{34}$

Figure 4 and Appendix Table 1 present annual real and nominal returns for the U.K. corporate bond market over the period 1861-2002. ${ }^{35}$ As can be clearly seen from the difference between the real and nominal returns, inflation had a substantial effect on the corporate bond market during World War I and in the 1970s. Table 1 examines real bond returns and compares them to real returns on equity and government bonds in four distinct inflationary periods - (a) 1861-1913, a period of low and stable inflation; (b) 1914-1967, which contains two bouts of

\footnotetext{
${ }^{32}$ Returns are unweighted as we do not have weights after 1946, and value weighting before 1946 means that the annual returns up to that point are dominated by a few large railways.

${ }^{33}$ The Register of Defunct Companies was published in 1979 and contains notices of companies removed from the Stock Exchange Yearbook from 1875 to 1979. Subsequent defunct companies were included in an annual supplement of the Stock Exchange Yearbook.

${ }^{34}$ In a small number of cases, where the Register of Defunct Companies only stated that the "debenture holders were not paid in full," it is assumed that debenture holders lost 100 percent of their investment. Debenture holders may have relinquished claims to interest payments temporarily in order to allow a company to reconstruct. For example, debenture holders are said to have relinquished their rights to interest during the reconstruction of several iron and steel companies during the 1920s (see "Company Reconstructions," The Economist, May 7th 1932, p. 1039). Although we do not have systematic information or data, these were infrequent events and it is likely that such temporary relinquishments would have been reflected in debenture prices.

${ }^{35}$ In terms of extant estimates of the performance of the bond market, our series of nominal returns is highly correlated with Smith and Horne's (1934) index of fixed interest securities for 1867-1933 (correlation coefficient $=0.86)$ as well as Edelstein's $(1975,2010)$ series of debenture returns for 1870-1913 (correlation coefficient $=0.87$ ). Glyn $(1973$, p. 236) provides four estimates of debenture yields for 1955-1958, 1959-1962, 1962-1965, and 1966-1969. His estimates for these periods are lower than ours because he subtracts income tax from the bond yields and he has a much smaller sample than we have.
} 


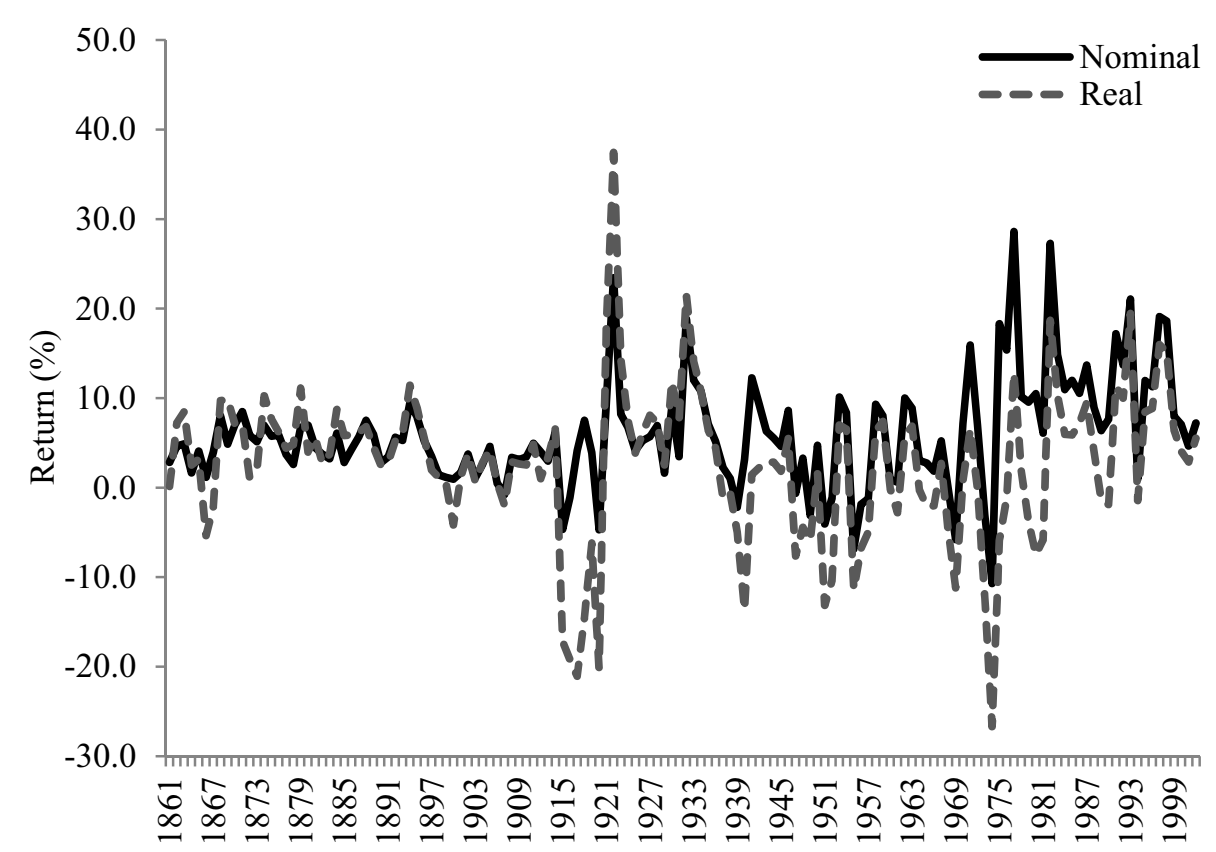

FIGURE 4

NOMINAL AND REAL DEBENTURE RETURNS, 1861-2002

Notes: Debenture log returns are shown, and are adjusted to take account of losses incurred due to company liquidation. Data on payments to debenture-holders in the event of liquidation were obtained from Stock Exchange (1979) and annual supplements to the Stock Exchange Yearbook. Sources: Course of the Exchange (1860-1863); Investor's Monthly Manual (1864-1929); Stock Exchange Daily Official List (1930-2002). O'Donoghue, Goulding, and Allen (2004) is used to convert nominal into real returns.

wartime inflation; (c) 1968-1981, a period of high and volatile inflation which started with the devaluation of sterling and ended with the Conservative government's successful attempts to reduce inflation; and (d) 1982-2002, a period when inflation was gradually brought under control. Three things stand out from Table 1. First, the real return on corporate bonds, which averaged 4.14 percent in the pre-1913 era, was only 1.09 percent in 1914-1967, which was largely due to wartime inflation. For example, if we remove the negative returns in 1915-1920, the arithmetic mean rises to 3.27 percent. ${ }^{36}$ Second, the real return during the period 1968-1981, when annual inflation in the U.K.

\footnotetext{
${ }^{36}$ The wartime experience of negative real returns on debentures led T. S. Eliot, the poet, to comment that "everything is in question, even the fundamental dogma of modern society that debentures are safer than common stocks." Quoted in Raynes (1928, p. 46). Notably, actuaries began to develop a new investment strategy whereby insurance companies invested a greater of proportion of funds in ordinary stocks rather than debentures (Raynes 1928).
} 
TABLE 1

ANNUAL RETURNS ON U.K. DEBENTURE MARKET, 1861-2002 (percent)

\begin{tabular}{cccccc}
\hline \hline & Arithmetic \\
Mean & $\begin{array}{c}\text { Geometric } \\
\text { Mean }\end{array}$ & $\begin{array}{c}\text { Standard } \\
\text { Deviation }\end{array}$ & $\begin{array}{c}\text { Max. } \\
\text { Return }\end{array}$ & $\begin{array}{c}\text { Min. } \\
\text { Return }\end{array}$ & $\begin{array}{c}\text { Percentage of } \\
\text { Years }<0\end{array}$ \\
\hline
\end{tabular}

Panel A: Debenture returns, 1861-2002

\begin{tabular}{lllllll} 
Nominal & 5.96 & 5.80 & 6.04 & 28.59 & -10.71 & 11.27 \\
Real & 2.72 & 2.36 & 8.46 & 37.44 & -26.71 & 28.17 \\
\hline
\end{tabular}

Panel B: Real debenture returns for subperiods

\begin{tabular}{rrrrrrr}
$1861-1913$ & 4.14 & 4.08 & 3.65 & 11.45 & -5.35 & 7.55 \\
$1914-1967$ & 1.09 & 0.53 & 10.72 & 37.44 & -21.06 & 42.59 \\
$1968-1981$ & -4.10 & -4.55 & 9.32 & 12.79 & -26.71 & 71.43 \\
$1982-2002$ & 7.85 & 7.69 & 6.06 & 19.45 & -1.88 & 14.29 \\
\hline
\end{tabular}

Panel C: Real returns on the equity market

\begin{tabular}{rrrrrrr}
$1861-2002$ & 7.63 & 5.97 & 18.92 & 121.40 & -64.80 & 28.87 \\
$1861-1913$ & 7.57 & 7.28 & 8.00 & 28.29 & -4.40 & 20.75 \\
$1914-1967$ & 6.21 & 4.76 & 17.88 & 50.50 & -34.10 & 37.04 \\
$1968-1981$ & 9.04 & 0.96 & 43.66 & 121.40 & -64.80 & 42.86 \\
$1982-2002$ & 10.50 & 9.27 & 16.02 & 27.50 & -24.00 & 23.81 \\
\hline
\end{tabular}

Panel D: Real returns on government debt market

$\begin{array}{rrrrrrr}1861-2002 & 2.01 & 1.37 & 11.53 & 44.50 & -33.40 & 41.55 \\ 1861-1913 & 2.41 & 2.34 & 3.73 & 10.83 & -7.33 & 24.53 \\ 1914-1967 & 0.04 & -0.82 & 13.42 & 41.50 & -23.30 & 57.41 \\ 1968-1981 & -3.44 & -4.63 & 15.86 & 31.90 & -33.40 & 78.57 \\ 1982-2002 & 9.70 & 9.01 & 12.90 & 44.50 & -13.60 & 23.81\end{array}$

Notes: Debenture log returns are shown, and are adjusted to take account of losses incurred due to company liquidation. Data on payments to debenture-holders in the event of liquidation were obtained from Stock Exchange (1979) and annual supplements to the Stock Exchange Yearbook.

Sources: Debenture returns are calculated from debenture data obtained from Course of the Exchange (1860-1863), Investor's Monthly Manual (1864-1929), Stock Exchange Daily Official List (1930-2002). O'Donoghue, Goulding, and Allen (2004) is used to convert the nominal returns into real terms. Equity returns are from Acheson et al. (2009) for 1860-1870; Grossman (2002) for 1871-1913; and Dimson, Marsh, and Staunton (2011, pp. 164-66) for 1914-2002. The returns on the government debt market are based on Consol prices for the period 1860 to 1955 , and from 1955, a portfolio of high-coupon, long-dated bonds. Consol yields and government bond yields were hand collected from the Course of the Exchange for 1860-1871; the annual Statistical Abstract for the United Kingdom for 1871-1913; and Dimson, Marsh, and Staunton (2011, pp. 164-66) for 1914-2002. 


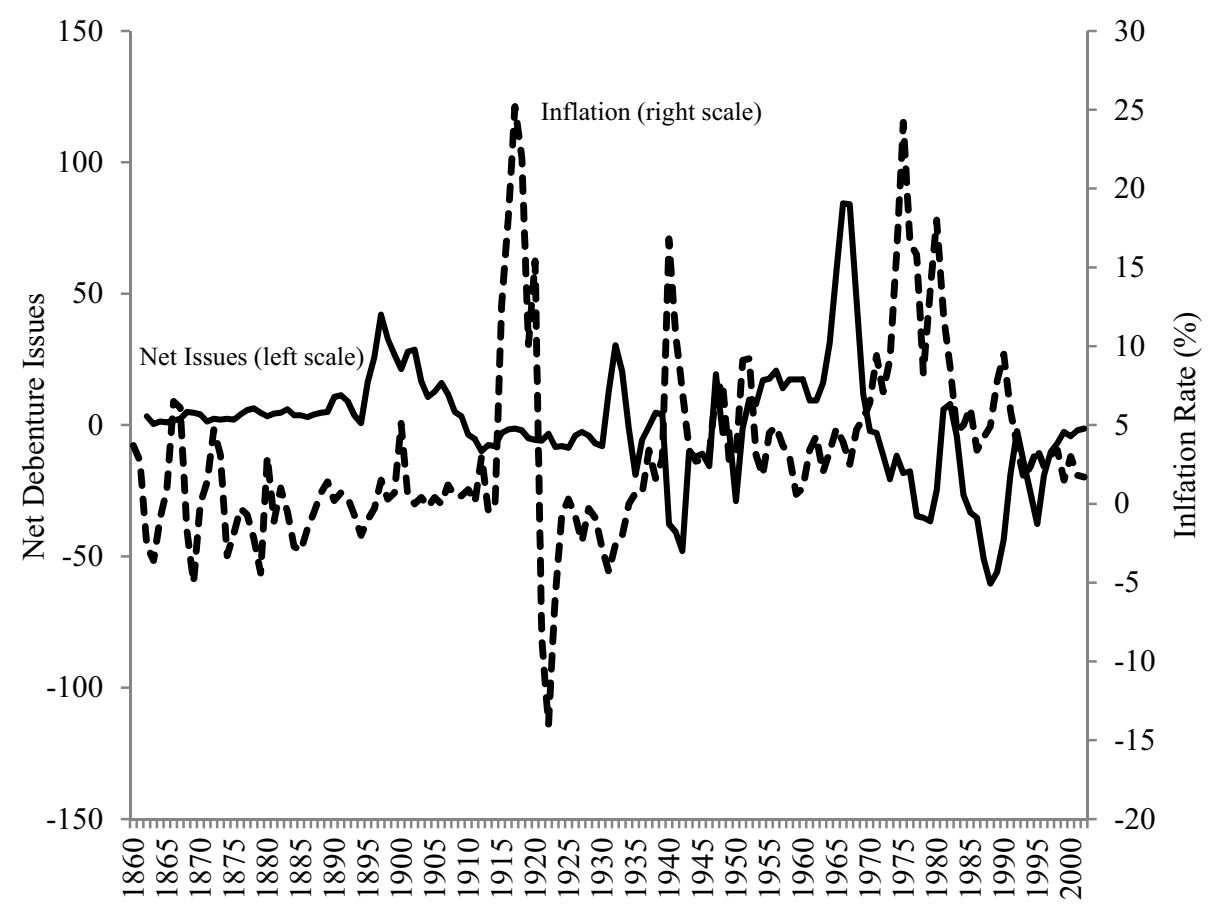

FIGURE 5

NET DEBENTURE ISSUES (THREE-YEAR MOVING AVERAGE) AND INFLATION RATE, 1860-2002

Notes: Net debenture issues for each year are calculated by subtracting the number of debenture redemptions from the number of new issues.

Sources: Course of the Exchange (1860-1863); Investor's Monthly Manual (1864-1929); Stock Exchange Daily Official List (1930-2002). The inflation rate is from O’Donoghue, Goulding, and Allen (2004).

averaged 11.7 percent, was -4.10 percent. Conversely, equities enjoyed a high real average return in this period, whilst government bond returns were as dismal as those of corporate bonds. It is not surprising that inflation kept investors away from the corporate bond market at this time. Third, the high real return in the 1982-2002 period is partially due to firms having to pay higher coupons on their bonds to attract investors following the high inflation of 1968-1981.

Figure 5 reveals that the inflation which started in the late 1960s was followed by negative net debenture issues for nearly every year for the rest of the sample period, apart from 1980 and 1981, when a large number of property companies issued debentures. As can be seen from Figure 6, there was a substantial fall in the number of debenture 


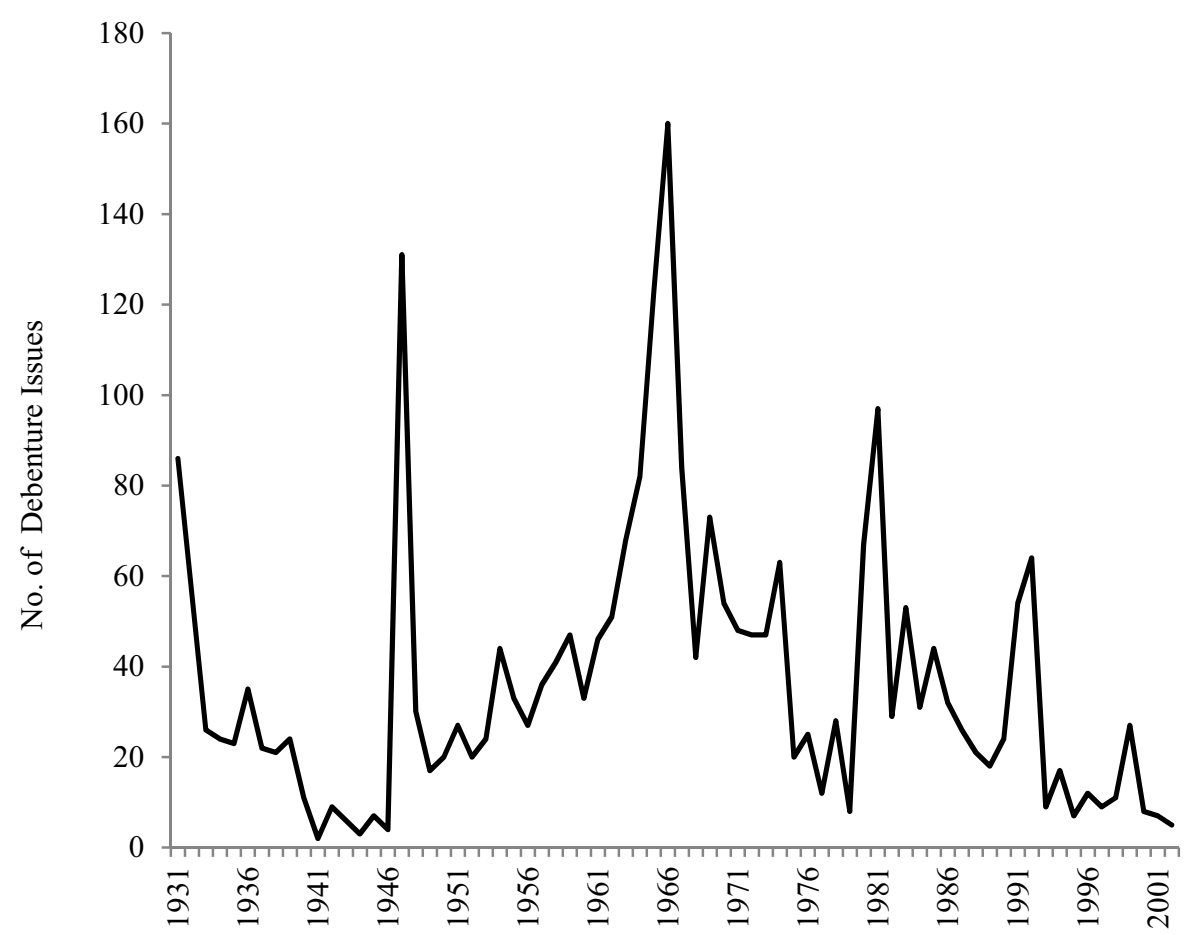

FIGURE 6

DEBENTURE ISSUES, 1931-2002

Sources: Stock Exchange Daily Official List (1931-2002).

issues in the $1970 \mathrm{~s}$, but the post-1970 negative net issues is also attributable to the fact that many companies with maturing bonds did not issue replacements. By way of contrast, equity issues, which, as mentioned above, had been relatively low during the 1960s, increased substantially in the 1970s and 1980s (Rajan and Zingales 2003, table 4).

We construct a series of three-factor vector auto regression (VAR) models and use Granger causality tests to determine whether inflation provides statistically significant information about future debenture issues and debenture returns. Our basic hypothesis is that inflation Granger causes debenture issues and returns. We also look at the relationships between inflation, nominal returns, current bond yields, the bond risk premium, and issues. Each time series is tested for unit roots using Augmented Dickey-Fuller tests: we find that inflation, yield, and bond risk premium are non-stationary. Consequently, these series are differenced when analyzing the relationship between them and 
the other variables. The lag length (i.e., the length of time before inflation affects issues returns) is determined by the Akaike information criterion. ${ }^{37}$

Over the entire sample period, we find (results not tabulated) that inflation does not Granger cause debenture issues, which is not surprising given that inflation was constrained by the gold standard for the majority of our sample. However, whenever we focus on the period after sterling devaluation in 1967, inflation Granger causes debenture issues in every VAR specification in Table 2. In contrast to the United Kingdom, inflation in the United States in the 1970s (and 1980s) was a lot lower and less volatile. For example, the average and standard deviation of the annual inflation rate between 1970 and 1980 was 7.7 and 3.2 percent for the United States, while it was 13.1 and 5.6 percent for the United Kingdom. ${ }^{38}$ In addition, at its peak in 1974-1977, the U.K. inflation rate averaged 18.2 percent, whilst the U.S. rate was only 8.1 percent. Consequently, the U.S. corporate bond market was less affected by inflation, and once inflation fell in the early 1980s, this market, unlike that of the United Kingdom, experienced substantial growth (Jefferis 1990; Schinasi and Smith 1998).

Although the Wilson Committee (1980, p. 237) in 1980 identified the moribund state of the corporate bond market as a serious weakness of the British financial system, the market has never been revived. The Wilson Committee (1980, p. 225) argued that risk aversion on the part of borrowers and lenders, arising from inflation, prevented agreement being reached on appropriate nominal rates. One puzzle is why indexation did not take off in the corporate bond market. The Wilson Committee's (1980, p. 237) 1978 survey of firms suggests that managers were reluctant to accept open-ended and potentially nominal terms large liabilities that could fall due at inopportune times. Their fears were reasonable given that U.K. inflation was volatile as well as high in the 1970s.

\section{Tax Shield}

Debt financing is attractive to companies when interest is treated as a cost and thus removed from accounting profits, and when taxes on net income are substantial (Modigliani and Miller 1963;

\footnotetext{
${ }^{37}$ The criterion is superior to other tests of lag selection when sample size is under 60 . However, our findings are robust to using alternative tests such as the Hannan-Quinn information criterion or the Schwartz Bayesian information criterions. See Liew (2004).

${ }^{38}$ Inflation data is from Williamson (2011).
} 
TABLE 2

GRANGER CAUSALITY TESTS OF FACTORS AFFECTING DEBENTURE ISSUES, $1967-2002$

\begin{tabular}{llll}
\hline \hline Dependent Variables & \multicolumn{1}{c}{ Independent Variables } & \multicolumn{1}{c}{$\chi^{2}$} & p-value \\
\hline Panel $A$ & & & \\
Issues & Inflation & $7.674^{* * *}$ & 0.006 \\
Issues & Risk spread & 1.230 & 0.267 \\
Issues & All & $7.831^{* *}$ & 0.020 \\
Risk spread & Inflation & $9.380^{* * *}$ & 0.002 \\
Risk spread & Issues & 0.050 & 0.822 \\
Risk spread & All & $9.902^{* * *}$ & 0.007 \\
& & & \\
Panel B & & & \\
Issues & Inflation & $5.406^{*}$ & 0.067 \\
Issues & Nominal return & 1.159 & 0.560 \\
Issues & All & $8.703^{*}$ & 0.069 \\
Nominal return & Inflation & $5.607^{*}$ & 0.061 \\
Nominal return & Issues & $4.624^{*}$ & 0.099 \\
Nominal return & All & $11.656^{* *}$ & 0.020 \\
& & & \\
Panel C & & & \\
Issues & Inflation & $9.924^{* * *}$ & 0.007 \\
Issues & Yield & 4.039 & 0.133 \\
Issues & All & $12.167^{* *}$ & 0.016 \\
Yield & Inflation & $10.754^{* * *}$ & 0.005 \\
Yield & Issues & 3.523 & 0.172 \\
Yield & All & $13.366^{* * *}$ & 0.010 \\
\hline
\end{tabular}

* indicates statistical significance at the 10 percent level.

** indicates statistical significance at the 5 percent level.

*** indicates statistical significance at the 1 percent level.

Notes: Table presents Granger-causality test statistics $\left(\chi^{2}\right)$ as well as their $p$-values. The dependent variable of the three-factor VAR model for each test is in the first column and independent variable is in the second column. Issues is the number of debenture issues; Inflation is the rate of change in the U.K.'s composite price index; Risk spread is the difference between the yield on debentures and government bonds; Yield is the average current yield on debentures; Coupon is the average coupon rate on debentures. Inflation, Yield, and Risk spread variables are differenced as the ADF tests reveal non-stationarity. Lag length is chosen using Akaike information criterion (AIC). One lag is used in panel A and two lags are used in panels $\mathrm{B}$ and $\mathrm{C}$.

Kemsley and Nissim 2002). Second, when taxation weights on distributed (but not retained) profits then debt finance can be very attractive to companies. Third, if the taxation of dividend income is more severe than interest, then companies will cater to investor preferences for bonds over shares. 
The Labour government introduced a profit tax in 1947. The tax was higher for profits distributed to shareholders $(25$ percent) than for profits retained within the company $(10$ percent $) .{ }^{39}$ The Labour government hoped to limit what was viewed as unmerited income, whilst at the same time encouraging companies to invest in new plant and machinery (Daunton 2002, pp. 201, 248). As interest could be charged against taxable profits, the large increase in the tax rate on distributed profits made debt capital much cheaper to service than equity. Shareholders' reduced dividend income, allied to the fact that share repurchases in this period were illegal, further depressed the demand for equity. As banks in the late 1940s held over 80 percent of their deposits in some form of government debt, they were unable to provide the funds required by companies (Sheppard 1971, pp. 126-27). Consequently, as can be seen from Figure 6, there was a huge spike in debenture issues in 1947, the bond market grew steadily after 1949 (Figure 1). According to W. A. Thomas, tax policy, rather than difficulties in raising equity finance, was the most important influence on the volume of debentures in this period (Thomas 1978, p. 154). The Conservative budget of March 1958, replaced the differential system of profit tax with a single 10 percent tax on all profit. This reform marginally reduced the incentive to use debt borrowing, yet there was no diminution in the size of the debenture market (Figure 1). ${ }^{40}$

In 1965 the Labour government replaced the system of profits tax with a single corporate income tax (initially set at 40 percent) levied on profits. It also introduced a surtax on dividends. The resulting structure was broadly equivalent to the 1947-1958 tax regime save that distributed profits were taxed a lot more heavily than before. The Labour government's goal was to induce companies to retain earnings with the expectation that this would directly benefit the company's workers and result in a more equitable society (Daunton 2002, pp. 290-93). To ensure that these measures would not just result in investors taking profits as capital gains, the Labour government also introduced a long-term capital gains tax of 30 percent (Daunton 2002, p. 292). After 1965 companies' incentives to finance via debt rather than equity were larger than ever before (Thomas 1978, p. 154). And, as can be seen from Figure 6, they did just that, the number of debenture issues reached unprecedented levels in 1965 and 1966. The number of debentures on the U.K. market increased from 567 in 1964 to 801 by 1971 (see Appendix Table 1 for full details).

\footnotetext{
${ }^{39}$ See Daunton (2002, pp. 200-01). The rate for distributed profits increased to 30 percent in 1949, and in 1951 it was raised to 50 percent (Daunton 2002, pp. 210-11).

${ }^{40}$ See Thomas (1978, p. 154).
} 
Between 1964 and 1971, 22.25 billion was raised on the U.K. corporate bond market, twice as much as was raised on the equity market (Anon. 1981, pp. 54-56). ${ }^{41}$

In order to formally test the relationship between these tax changes and debenture issues, we regress a binary variable for the introduction of the new tax regimes upon debenture issues. As the post-1931 data sources are comprehensive, we focus on the 1931-2002 period. We create two binary variables: (a) Tax_l equals 1 in 1947 and 1965 , the years in which profits and corporation tax are introduced respectively, and 0 otherwise; and (b) Tax_2 equals 1 in 1947, 1948, 1965, and 1966, the years of and years just after the taxation changes, and 0 otherwise. In essence, what we are testing is whether the majority of the population of public companies on the market immediately exploits the tax changes. If they do so, as is suggested by Figure 6, then we should not expect above-trend new issues thereafter. The regression results in Table 3 indicate that these tax changes had a statistically and economically significant effect on debenture issues, with the tax-change variables alone explaining 23 and 33 percent of the time-series variation in debenture issues.

\section{Supply of Capital}

Did the variation in the importance of the U.K. corporate bond market have a big effect on the supply of capital to firms? Although this question is somewhat beyond the scope of this article, one way of looking at the effect of bond market variation on the overall supply of capital is to look at the proportion of gross fixed capital formation financed via equity and corporate bonds. ${ }^{42}$ In 1938 and 1960 this ratio was 0.12 and 0.11 , but due to the inflation-induced fall in the new issue of bonds, the ratio fell to 0.03 in 1970 and 0.04 in 1980. It increased in 1990 and 1999 to 0.07 and 0.09 respectively thanks to an increase in new equity issues. This evidence is consistent with the view that the contraction of the bond market may have had a detrimental effect on the supply of finance from the capital market.

\footnotetext{
${ }^{41}$ There was also a tax-induced increase in the use of unsecured loan stock during this period. Notably, the tax advantage of debt meant that the conversion of convertible loan stock at this time was often deferred, with the result that, despite their initial short-term nature, many of these securities had terms in excess of five years (Thomas 1978, pp. 156-57).

${ }^{42}$ Gross fixed capital formation data was obtained from Sefton and Weale (1996, table A2) and the Office for National Statistics. Equity issues are from Rajan and Zingales (2003, table 4).
} 
TABLE 3

EFFECT OF TAX CHANGES ON DEBENTURE ISSUES, 1931-2002

(1)

\begin{tabular}{cc}
\hline Tax_1 & $92.886^{* * *}$ \\
& $(19.322)$
\end{tabular}

Tax_2

Constant

Adjusted $R$-squared

No. of observations

\section{(19.322)}

$34.114^{* * *}$

(3.220)

0.238

72
(2)

\footnotetext{
*** indicates statistical significance at the 1 percent level.

Notes: Dependent variable is number of debenture issues. Tax_l equals 1 in 1947 and 1965, the years in which profits and corporation tax are introduced respectively, and 0 otherwise. Tax_2 equals 1 in 1947, 1948, 1965, and 1966, the years of and years after the taxation changes, and 0 otherwise.
}

Did the size of the bond market affect the use of debt within firms? In order to see whether the size of the bond market affected the use of debt within firms, we look at debt-equity ratios of the constituents of the Financial Times' FT-30 Index (the United Kingdom's equivalent of the Dow Jones). Prior to 1995 the constituents of this index seldom changed and were all industrial and commercial companies. From Table 4, we see that the average debt-equity ratio is high in 1913 when the corporate bond market was in its heyday in terms of value, and it is high in 1995 when the corporate bond market was very small. In 1935, in the middle of a period of bond market contraction, debt-equity ratios are very low. However, average debt-equity ratios had increased by 1965 , when the bond market was in the middle of its renaissance. In other words, apart from in 1995, the variation in debt-equity ratios appears to reflect the variation in the size of the bond market.

Why is the debt-equity ratio so high in 1995 whenever the corporate bond market had contracted? One possibility is that multinational companies increasingly borrowed on international stock markets and the Eurobond market. ${ }^{43}$ However, this only applies to the largest publicly traded companies. A better explanation is that banks stepped into the gap left by the collapse of the corporate bond market. The increase in bank lending to companies since the early 1970 s has been dramatic,

\footnotetext{
${ }^{43}$ A Eurobond is a bond denominated in a currency foreign to that of the country where it is issued e.g., a U.K. firm could issue a yen-denominated bond in London. These bonds are typically traded OTC and are held by institutional investors.
} 
TABLE 4

DEBT-EQUITY RATIOS OF COMPANIES IN FT-30 INDEX, 1913-1995

\begin{tabular}{lcc}
\hline \hline & $\begin{array}{c}\text { Mean Debt-Equity Ratio } \\
(\%)\end{array}$ & $\begin{array}{c}\text { Median Debt-Equity Ratio } \\
(\%)\end{array}$ \\
\hline 1913 & 63.41 & 53.36 \\
1935 & 22.96 & 8.07 \\
1965 & 45.69 & 39.07 \\
1995 & 59.37 & 53.51 \\
\hline
\end{tabular}

Notes: The FT-30 Index, which was originally the Financial News' FN-30 Index, commenced in 1935; 24 of the 1935 constituents existed in 1913; these plus six additional large commercial / industrial companies are included in the figures for that year.

Sources: Company accounts for 1995 from Bloomberg, and 1913, 1935, and 1965 company accounts are from Stock Exchange Official Yearbooks.

with banks financing the majority of companies' borrowing requirement (Thomas 1978, p. 327; Anon. 1981, p. 57). As can be seen from Figure 7, the contraction of the debenture market coincides with the rapid growth in bank lending in the United Kingdom. Banks did not lend much to U.K. public companies prior to the 1960 s as they were constrained by government directives which constrained lending to businesses and essentially tied up large proportions of bank deposits in government debt (Nevin and Davis 1970, p. 274; Wadsworth 1973, p. 106). For example, in 1950 holdings of government debt by U.K. banks were equal to 58 percent of bank deposits (Sheppard 1971, p. 127). These constraints were gradually removed during the 1960s and 1970s, and this combined with the entrance of foreign banks into London meant that lending, particularly to businesses, was able to expand dramatically.

Notably, the remarkable increase in the number of multiple firm-bank relationships observed in the 1970s is consistent with this growth in bank lending to publicly traded companies (Braggion and Ongena 2011). U.K. banks, as powerful and concentrated incumbents, may have had incentives to frustrate the renaissance of the domestic corporate bond market (Schinasi and Smith 1998, pp. 27-30; Rajan and Zingales 2003). ${ }^{44}$ Alternatively, as the banking and shadow-banking systems increasingly met the borrowing needs of firms, there may have been less need for a domestic corporate debt market.

What the above evidence seems to suggest is that during the first 100 years of the U.K. bond market's existence, if public companies wanted to finance via debt, the corporate bond market was the only important source of debt finance. However, after the 1960s the rise of the Eurobond OTC markets and the huge increase in bank lending to industry meant that there were substitutes for corporate bonds. 


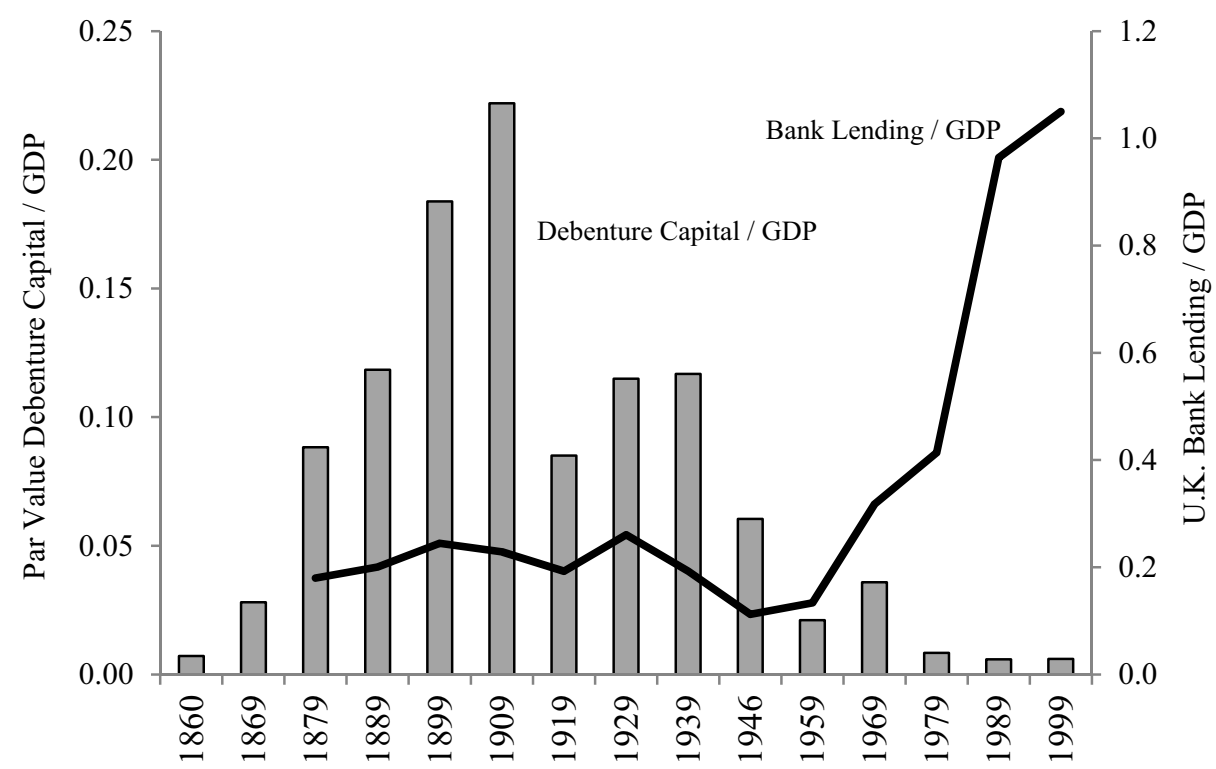

FIGURE 7

VALUE OF DOMESTIC DEBENTURES TRADED ON U.K. STOCK EXCHANGES AND BANK LENDING, 1860-1999

Notes: Sheppard's figure for 1880 is used as an estimate for 1879.

Sources: Course of the Exchange (1860-1863); Investor's Monthly Manual (1864-1929); Stock Exchange Daily Official List (1930-1999); Stock Exchange Official Yearbook (1959-1999). GDP data is from Officer (2011). Loans and advances of U.K. banks for 1880-1959 from Sheppard (1971) and M4 lending for 1969-1999 from the Bank of England (http://www.bankofengland.co.uk/statistics/Pages/abstract/part2.aspx).

\section{CONCLUSION}

After experiencing over half a century of growth, the U.K. corporate bond market suffered a great reversal in the twentieth century. Structural theories about legal origin and creditor protection cannot explain this phenomenon as creditor protection scores remain unchanged over the entire sample period. Indeed, investor protection legislation and the common law cannot even be credited with stimulating the takeoff of the U.K. debenture market.

We test two explanations for the twentieth-century variation in the U.K. corporate bond market. First, we find that inflation was a major cause of the decline of the market from the late $1960 \mathrm{~s}$ onwards. The very high inflation in the 1970s and 1980s drove the market down in several ways. Inflation and the uncertainty it caused, eroded the real value of corporate bonds and accelerated bond redemptions without a counterbalancing rise in new issues (Anon. 
1981, p. 56; Wilson Committee 1980, pp. 19 and 225). Second, we find that government taxation policies after World War II provided a large incentive to companies to use debt finance. Not only was there the classic tax shield (i.e., interest payments on debt could reduce taxable profits), but there was also a higher tax rate if profits were distributed rather than being retained. Given the constraints on bank lending, companies turned to the corporate bond market. As a result, this market reached its zenith, in terms of the number of debentures traded on the market, in the late 1960s.

Although inflation and taxation policies are visible causes of the variation in the twentieth-century U.K. corporate bond market, they themselves are driven by political economy. The main underlying driving force which may explain the postwar renaissance and post-1970 decline in the U.K. corporate bond market is the growth of social democracy. The advocates of social democratic economic policy in the United Kingdom were empowered by the combination of universal suffrage and the human and physical destruction experienced during World War II. ${ }^{45}$ The voters of the post-World War II period brought to power a government who intended to rebuild the U.K. economy with a combination of government spending on housing and infrastructure and privately funded capital deepening. The tax-induced renaissance of the bond market was an indirect consequence of the postwar Labour government's attempts to redistribute income, stimulate investment, and limit what it perceived to be unmerited income (i.e., dividends). The high inflation of the 1970s had some of its roots in the policy choices of the prevailing social democratic preferences of U.K. voters. The unwillingness of successive U.K. governments in the 1970s to implement contractionary monetary and fiscal policies to combat high inflation was driven by the fear that such policies would result in the then-powerful trade unions fomenting industrial unrest.

\footnotetext{
${ }^{45}$ Roe (2006) argues that the devastation wrought during the two world wars determines the strength of modern stock markets.
} 


\section{Appendix}

APPENDIX TABLE 1A

U.K. CORPORATE BOND MARKET, 1860-2002

\begin{tabular}{|c|c|c|c|c|}
\hline \multirow[b]{2}{*}{ Year } & \multirow[b]{2}{*}{ No. of Debentures } & \multicolumn{3}{|c|}{$\begin{array}{c}\text { Sectoral Breakdown of No. of Debentures } \\
(\%)\end{array}$} \\
\hline & & Railways & Breweries & $\begin{array}{c}\text { Commercial and } \\
\text { Industrial }\end{array}$ \\
\hline 1860 & 9 & 100.00 & - & - \\
\hline 1861 & 8 & 100.00 & - & - \\
\hline 1862 & 10 & 100.00 & - & - \\
\hline 1863 & 10 & 100.00 & - & - \\
\hline 1864 & 12 & 83.33 & - & 8.33 \\
\hline 1865 & 13 & 84.62 & - & 7.69 \\
\hline 1866 & 15 & 86.67 & - & 6.67 \\
\hline 1867 & 19 & 89.47 & - & 5.26 \\
\hline 1868 & 28 & 92.86 & - & 3.57 \\
\hline 1869 & 29 & 93.10 & - & 3.45 \\
\hline 1870 & 31 & 93.55 & - & 3.22 \\
\hline 1871 & 32 & 93.75 & - & 3.13 \\
\hline 1872 & 36 & 94.44 & - & 2.78 \\
\hline 1873 & 37 & 94.59 & - & 2.70 \\
\hline 1874 & 39 & 92.31 & - & 2.56 \\
\hline 1875 & 42 & 90.48 & - & 2.38 \\
\hline 1876 & 49 & 91.84 & - & 2.04 \\
\hline 1877 & 56 & 89.29 & - & 1.79 \\
\hline 1878 & 61 & 85.25 & - & 3.28 \\
\hline 1879 & 63 & 84.13 & - & 3.17 \\
\hline 1880 & 66 & 81.82 & - & 4.55 \\
\hline 1881 & 74 & 79.73 & - & 4.05 \\
\hline 1882 & 77 & 80.52 & - & 3.90 \\
\hline 1883 & 84 & 80.95 & - & 3.57 \\
\hline 1884 & 85 & 79.76 & - & 4.76 \\
\hline 1885 & 88 & 80.23 & - & 4.65 \\
\hline 1886 & 93 & 79.12 & - & 4.40 \\
\hline 1887 & 97 & 75.79 & 2.11 & 6.32 \\
\hline 1888 & 102 & 72.00 & 5.00 & 6.00 \\
\hline 1889 & 108 & 66.98 & 7.55 & 8.49 \\
\hline 1890 & 129 & 58.40 & 12.80 & 11.20 \\
\hline 1891 & 136 & 56.06 & 15.15 & 10.61 \\
\hline 1892 & 135 & 51.54 & 16.15 & 13.08 \\
\hline 1893 & 140 & 50.37 & 17.78 & 12.59 \\
\hline 1894 & 126 & 53.66 & 22.76 & 1.63 \\
\hline 1895 & 184 & 38.07 & 23.86 & 19.89 \\
\hline 1896 & 217 & 31.40 & 28.99 & 22.71 \\
\hline 1897 & 264 & 29.03 & 30.24 & 26.21 \\
\hline 1898 & 282 & 27.00 & 31.18 & 27.76 \\
\hline 1899 & 297 & 25.54 & 30.94 & 29.50 \\
\hline 1900 & 328 & 23.28 & 31.48 & 28.52 \\
\hline 1901 & 366 & 21.28 & 28.86 & 31.20 \\
\hline 1902 & 383 & 20.28 & 28.61 & 31.39 \\
\hline 1903 & 378 & 17.46 & 29.01 & 32.96 \\
\hline 1904 & 398 & 18.93 & 28.00 & 32.80 \\
\hline 1905 & 421 & 18.41 & 26.85 & 33.76 \\
\hline 1906 & 426 & 18.34 & 27.39 & 33.67 \\
\hline 1907 & 433 & 19.31 & 26.98 & 32.67 \\
\hline
\end{tabular}


Great Reversal of the U.K. Corporate Debt Market 837

APPENDIX TABLE 1A - continued

\begin{tabular}{|c|c|c|c|c|}
\hline \multirow[b]{2}{*}{ Year } & \multirow[b]{2}{*}{ No. of Debentures } & \multicolumn{3}{|c|}{$\begin{array}{c}\text { Sectoral Breakdown of No. of Debentures } \\
(\%)\end{array}$} \\
\hline & & Railways & Breweries & $\begin{array}{l}\text { Commercial and } \\
\text { Industrial }\end{array}$ \\
\hline 1908 & 436 & 19.41 & 27.03 & 31.45 \\
\hline 1909 & 436 & 19.66 & 26.78 & 31.94 \\
\hline 1910 & 422 & 19.49 & 26.84 & 31.90 \\
\hline 1911 & 420 & 19.64 & 26.53 & 32.14 \\
\hline 1912 & 406 & 20.11 & 26.19 & 31.22 \\
\hline 1913 & 399 & 20.43 & 26.08 & 30.65 \\
\hline 1914 & 396 & 20.71 & 26.43 & 30.52 \\
\hline 1915 & 397 & 20.38 & 26.90 & 30.43 \\
\hline 1916 & 394 & 20.55 & 27.12 & 30.68 \\
\hline 1917 & 392 & 20.66 & 27.27 & 30.58 \\
\hline 1918 & 391 & 20.78 & 27.42 & 29.64 \\
\hline 1919 & 379 & 21.55 & 27.59 & 29.02 \\
\hline 1920 & 375 & 21.87 & 27.70 & 28.28 \\
\hline 1921 & 373 & 22.19 & 27.22 & 27.81 \\
\hline 1922 & 369 & 18.18 & 27.58 & 28.48 \\
\hline 1923 & 350 & 9.84 & 30.16 & 31.48 \\
\hline 1924 & 349 & 8.97 & 29.24 & 30.90 \\
\hline 1925 & 343 & 6.85 & 29.45 & 31.16 \\
\hline 1926 & 338 & 7.07 & 30.04 & 31.10 \\
\hline 1927 & 341 & 7.42 & 30.39 & 30.04 \\
\hline 1928 & 331 & 7.75 & 31.73 & 28.41 \\
\hline 1929 & 317 & 8.24 & 32.55 & 29.02 \\
\hline 1930 & 463 & 5.59 & 31.94 & 36.13 \\
\hline 1931 & 516 & 5.47 & 31.93 & 38.32 \\
\hline 1932 & 554 & 5.66 & 32.25 & 37.91 \\
\hline 1933 & 524 & 4.04 & 34.50 & 36.51 \\
\hline 1934 & 512 & 3.94 & 34.90 & 36.59 \\
\hline 1935 & 497 & 3.90 & 35.67 & 34.89 \\
\hline 1936 & 507 & 3.85 & 34.49 & 34.10 \\
\hline 1937 & 510 & 4.05 & 35.45 & 33.14 \\
\hline 1938 & 511 & 4.05 & 35.45 & 33.33 \\
\hline 1939 & 519 & 4.17 & 35.48 & 33.59 \\
\hline 1940 & 397 & 5.49 & 32.92 & 32.92 \\
\hline 1941 & 389 & 5.67 & 32.99 & 32.73 \\
\hline 1942 & 375 & 6.17 & 31.90 & 33.24 \\
\hline 1943 & 366 & 6.37 & 32.13 & 31.86 \\
\hline 1944 & 353 & 6.55 & 32.76 & 30.77 \\
\hline 1945 & 342 & 6.78 & 33.63 & 30.09 \\
\hline 1946 & 319 & 7.23 & 34.59 & 28.30 \\
\hline 1947 & 411 & 5.10 & 33.50 & 33.25 \\
\hline 1948 & 333 & 0.30 & 40.77 & 40.18 \\
\hline 1949 & 311 & 0.32 & 44.13 & 44.76 \\
\hline 1950 & 324 & 0.31 & 43.56 & 46.93 \\
\hline 1951 & 329 & 0.30 & 44.31 & 49.40 \\
\hline 1952 & 340 & 0.29 & 44.35 & 49.86 \\
\hline 1953 & 348 & - & 41.93 & 52.41 \\
\hline 1954 & 380 & - & 39.74 & 54.29 \\
\hline 1955 & 393 & - & 38.69 & 54.27 \\
\hline 1956 & 410 & - & 38.22 & 54.57 \\
\hline 1957 & 422 & - & 36.51 & 56.05 \\
\hline 1958 & 445 & - & 34.96 & 57.52 \\
\hline 1959 & 462 & - & 33.76 & 58.39 \\
\hline
\end{tabular}


APPENDIX TABLE 1A - continued

\begin{tabular}{|c|c|c|c|c|}
\hline \multirow[b]{2}{*}{ Year } & \multirow[b]{2}{*}{ No. of Debentures } & \multicolumn{3}{|c|}{$\begin{array}{c}\text { Sectoral Breakdown of No. of Debentures } \\
(\%)\end{array}$} \\
\hline & & Railways & Breweries & $\begin{array}{l}\text { Commercial and } \\
\text { Industrial }\end{array}$ \\
\hline 1960 & 474 & - & 32.71 & 59.21 \\
\hline 1961 & 473 & - & 31.26 & 59.63 \\
\hline 1962 & 490 & - & 29.20 & 61.80 \\
\hline 1963 & 522 & - & 28.44 & 62.52 \\
\hline 1964 & 567 & - & 28.52 & 63.65 \\
\hline 1965 & 665 & - & 25.41 & 67.61 \\
\hline 1966 & 775 & - & 20.43 & 73.82 \\
\hline 1967 & 819 & - & 19.83 & 76.06 \\
\hline 1968 & 810 & - & 19.19 & 76.77 \\
\hline 1969 & 810 & - & 16.89 & 79.31 \\
\hline 1970 & 812 & - & 16.46 & 79.63 \\
\hline 1971 & 801 & - & 16.32 & 79.73 \\
\hline 1972 & 775 & - & 16.35 & 79.57 \\
\hline 1973 & 750 & - & 16.64 & 79.26 \\
\hline 1974 & 766 & 一 & 16.30 & 77.49 \\
\hline 1975 & 720 & - & 16.28 & 78.21 \\
\hline 1976 & 697 & - & 16.12 & 78.46 \\
\hline 1977 & 662 & - & 16.07 & 78.68 \\
\hline 1978 & 614 & - & 16.43 & 78.60 \\
\hline 1979 & 587 & - & 16.37 & 78.61 \\
\hline 1980 & 588 & - & 15.61 & 76.67 \\
\hline 1981 & 632 & - & 15.65 & 70.29 \\
\hline 1982 & 611 & - & 16.09 & 67.66 \\
\hline 1983 & 575 & - & 15.85 & 66.90 \\
\hline 1984 & 552 & - & 15.78 & 66.06 \\
\hline 1985 & 511 & - & 17.26 & 62.10 \\
\hline 1986 & 469 & - & 17.42 & 61.29 \\
\hline 1987 & 399 & - & 17.22 & 59.49 \\
\hline 1988 & 330 & - & 18.40 & 55.52 \\
\hline 1989 & 301 & - & 18.18 & 55.89 \\
\hline 1990 & 268 & - & 16.23 & 50.94 \\
\hline 1991 & 273 & - & 11.15 & 45.72 \\
\hline 1992 & 294 & - & 9.25 & 35.96 \\
\hline 1993 & 224 & - & 9.46 & 29.73 \\
\hline 1994 & 195 & - & 9.33 & 28.50 \\
\hline 1995 & 181 & - & 10.61 & 27.93 \\
\hline 1996 & 166 & - & 9.70 & 28.48 \\
\hline 1997 & 164 & - & 12.80 & 28.66 \\
\hline 1998 & 160 & - & 14.38 & 29.38 \\
\hline 1999 & 158 & - & 13.29 & 29.11 \\
\hline 2000 & 151 & - & 11.92 & 29.14 \\
\hline 2001 & 154 & - & 11.04 & 30.52 \\
\hline 2002 & 154 & - & 11.04 & 30.52 \\
\hline
\end{tabular}

Notes: Debenture log returns are shown, and are adjusted to take account of losses incurred due to company liquidation. Data on payments to debenture holders in the event of liquidation were obtained from Stock Exchange (1979) and annual supplements to the Stock Exchange Yearbook.

Sources: Course of the Exchange (1860-1863); Investor's Monthly Manual (1864-1929); Stock Exchange Daily Official List (1930-2002); Stock Exchange Official Yearbook (1959-1999). O'Donoghue, Goulding, and Allen (2004) is used to convert the nominal value into real terms. 
APPENDIX TABLE 1B

U.K. CORPORATE BOND MARKET, 1860-2002

\begin{tabular}{|c|c|c|c|c|}
\hline \multirow[b]{2}{*}{ Year } & \multicolumn{2}{|c|}{$\begin{array}{c}\text { Annual Returns } \\
(\%)\end{array}$} & \multicolumn{2}{|c|}{$\begin{array}{l}\text { Total Par Value of Debentures } \\
\qquad(\mathfrak{f})\end{array}$} \\
\hline & Nominal & Real & Nominal & Real \\
\hline 1860 & - & - & $5,800,101$ & $5,800,101$ \\
\hline 1861 & 2.84 & 0.14 & $5,290,101$ & $5,147,268$ \\
\hline 1862 & 4.66 & 7.26 & $5,640,344$ & $5,630,744$ \\
\hline 1863 & 4.88 & 8.48 & $5,701,527$ & $5,896,729$ \\
\hline 1864 & 1.64 & 2.54 & $12,158,558$ & $12,688,001$ \\
\hline 1865 & 4.06 & 3.16 & $11,382,650$ & $11,771,401$ \\
\hline 1866 & 1.15 & -5.35 & $11,997,620$ & $11,600,895$ \\
\hline 1867 & 3.97 & -2.13 & $13,019,041$ & $11,820,640$ \\
\hline 1868 & 8.03 & 9.73 & $22,920,366$ & $21,164,328$ \\
\hline 1869 & 4.86 & 9.86 & $28,234,086$ & $27,057,441$ \\
\hline 1870 & 7.04 & 7.04 & $36,797,028$ & $35,676,725$ \\
\hline 1871 & 8.48 & 7.08 & $41,203,781$ & $39,390,021$ \\
\hline 1872 & 5.87 & 1.17 & $48,941,486$ & $44,588,124$ \\
\hline 1873 & 5.13 & 2.03 & $55,662,402$ & $49,139,165$ \\
\hline 1874 & 6.96 & 10.26 & $62,231,061$ & $56,750,978$ \\
\hline 1875 & 5.75 & 7.65 & $68,513,739$ & $63,667,530$ \\
\hline 1876 & 5.85 & 6.15 & $77,404,763$ & $72,145,450$ \\
\hline 1877 & 3.72 & 4.42 & $87,243,501$ & $81,884,899$ \\
\hline 1878 & 2.60 & 4.80 & $95,639,526$ & $91,740,065$ \\
\hline 1879 & 6.72 & 11.12 & $100,828,506$ & $100,973,047$ \\
\hline 1880 & 6.98 & 3.98 & $105,894,483$ & $102,864,897$ \\
\hline 1881 & 4.46 & 5.56 & $113,529,682$ & $111,494,756$ \\
\hline 1882 & 3.73 & 2.73 & $117,343,328$ & $114,087,645$ \\
\hline 1883 & 3.23 & 3.73 & $125,281,703$ & $122,414,799$ \\
\hline 1884 & 6.07 & 8.77 & $132,062,447$ & $132,524,465$ \\
\hline 1885 & 2.81 & 5.81 & $136,504,317$ & $141,091,331$ \\
\hline 1886 & 4.28 & 5.88 & $136,204,619$ & $143,034,067$ \\
\hline 1887 & 5.67 & 6.17 & $153,482,372$ & $161,984,036$ \\
\hline 1888 & 7.51 & 6.81 & $157,650,377$ & $165,218,234$ \\
\hline 1889 & 5.97 & 4.57 & $176,739,623$ & $182,630,707$ \\
\hline 1890 & 2.77 & 2.57 & $228,086,817$ & $235,218,027$ \\
\hline 1891 & 3.42 & 2.72 & $208,297,610$ & $213,306,433$ \\
\hline 1892 & 5.62 & 5.22 & $220,656,732$ & $225,058,897$ \\
\hline 1893 & 5.27 & 5.97 & $259,484,990$ & $266,514,422$ \\
\hline 1894 & 9.45 & 11.45 & $264,507,999$ & $277,106,975$ \\
\hline 1895 & 7.85 & 8.85 & $295,681,562$ & $312,863,042$ \\
\hline 1896 & 5.24 & 5.54 & $292,320,368$ & $310,234,456$ \\
\hline 1897 & 3.48 & 1.98 & $316,657,000$ & $331,021,557$ \\
\hline 1898 & 1.42 & 1.12 & $332,093,463$ & $346,116,792$ \\
\hline 1899 & 1.13 & 0.43 & $339,495,369$ & $351,354,439$ \\
\hline 1900 & 0.94 & -4.16 & $354,280,348$ & $347,956,430$ \\
\hline 1901 & 1.67 & 1.17 & $367,810,782$ & $359,439,118$ \\
\hline 1902 & 3.75 & 3.75 & $382,330,861$ & $373,628,709$ \\
\hline 1903 & 1.08 & 0.68 & $366,029,189$ & $356,267,283$ \\
\hline 1904 & 2.61 & 2.81 & $415,321,306$ & $405,053,282$ \\
\hline 1905 & 4.61 & 4.21 & $427,202,565$ & $414,974,236$ \\
\hline 1906 & 0.50 & 0.50 & $431,698,834$ & $419,341,803$ \\
\hline 1907 & -0.77 & -1.97 & $440,144,725$ & $422,415,386$ \\
\hline 1908 & 3.38 & 2.88 & $450,976,834$ & $430,647,114$ \\
\hline 1909 & 3.14 & 2.64 & $455,465,242$ & $432,758,522$ \\
\hline 1910 & 3.43 & 2.53 & $453,622,009$ & $427,128,116$ \\
\hline 1911 & 4.94 & 4.84 & $458,392,358$ & $431,188,232$ \\
\hline
\end{tabular}


APPENDIX TABLE 1B - continued

\begin{tabular}{|c|c|c|c|c|}
\hline \multirow[b]{2}{*}{ Year } & \multicolumn{2}{|c|}{$\begin{array}{c}\text { Annual Returns } \\
(\%)\end{array}$} & \multicolumn{2}{|c|}{$\begin{array}{l}\text { Total Par Value of Debentures } \\
\qquad(£)\end{array}$} \\
\hline & Nominal & Real & Nominal & Real \\
\hline 1912 & 3.99 & 0.99 & $456,777,782$ & $416,779,392$ \\
\hline 1913 & 2.98 & 3.38 & $455,047,774$ & $416,861,678$ \\
\hline 1914 & 6.26 & 6.56 & $463,623,514$ & $425,991,924$ \\
\hline 1915 & -4.66 & -17.16 & $467,504,762$ & $375,863,370$ \\
\hline 1916 & -1.11 & -19.21 & $467,128,389$ & $307,584,274$ \\
\hline 1917 & 4.14 & -21.06 & $465,095,780$ & $229,071,924$ \\
\hline 1918 & 7.51 & -14.49 & $466,647,617$ & $179,272,271$ \\
\hline 1919 & 3.91 & -6.19 & $466,433,394$ & $161,091,785$ \\
\hline 1920 & -4.71 & -20.11 & $465,654,468$ & $136,056,062$ \\
\hline 1921 & 9.41 & 18.01 & $477,244,972$ & $151,434,667$ \\
\hline 1922 & 23.44 & 37.44 & $499,777,227$ & $180,786,194$ \\
\hline 1923 & 8.18 & 14.18 & $483,101,755$ & $185,239,363$ \\
\hline 1924 & 6.68 & 7.38 & $495,322,105$ & $191,254,580$ \\
\hline 1925 & 4.15 & 3.85 & $502,092,579$ & $193,287,200$ \\
\hline 1926 & 5.26 & 6.06 & $511,515,954$ & $198,490,172$ \\
\hline 1927 & 5.69 & 8.09 & $525,078,333$ & $208,643,029$ \\
\hline 1928 & 6.93 & 7.23 & $535,365,486$ & $213,368,883$ \\
\hline 1929 & 1.63 & 2.53 & $539,392,624$ & $216,908,656$ \\
\hline 1930 & 9.04 & 11.84 & $590,143,894$ & $243,962,409$ \\
\hline 1931 & 3.47 & 7.77 & $629,161,140$ & $271,275,888$ \\
\hline 1932 & 18.85 & 21.45 & $656,106,944$ & $290,249,378$ \\
\hline 1933 & 12.01 & 14.11 & $622,385,305$ & $281,113,522$ \\
\hline 1934 & 10.78 & 10.78 & $624,700,526$ & $282,159,240$ \\
\hline 1935 & 7.09 & 6.39 & $622,028,919$ & $278,985,885$ \\
\hline 1936 & 5.15 & 4.45 & $646,204,074$ & $287,799,871$ \\
\hline 1937 & 2.28 & -1.12 & $646,709,100$ & $278,231,951$ \\
\hline 1938 & 1.05 & -0.55 & $660,457,549$ & $279,600,560$ \\
\hline 1939 & -2.19 & -4.99 & $691,031,849$ & $284,352,766$ \\
\hline 1940 & 3.14 & -13.66 & $671,319,542$ & $229,832,800$ \\
\hline 1941 & 12.27 & 1.47 & $662,111,272$ & $202,198,791$ \\
\hline 1942 & 9.32 & 2.22 & $658,153,689$ & $186,719,901$ \\
\hline 1943 & 6.29 & 2.89 & $651,488,462$ & $178,544,774$ \\
\hline 1944 & 5.54 & 2.84 & $627,428,488$ & $167,308,301$ \\
\hline 1945 & 4.63 & 1.83 & $620,463,094$ & $160,818,302$ \\
\hline 1946 & 8.61 & 5.51 & $602,206,340$ & $151,247,644$ \\
\hline 1947 & -0.64 & -7.64 & - & - \\
\hline 1948 & 3.28 & -4.42 & - & - \\
\hline 1949 & -3.11 & -5.91 & - & - \\
\hline 1950 & 4.71 & 1.61 & - & - \\
\hline 1951 & -4.05 & -13.15 & - & - \\
\hline 1952 & -1.14 & -10.34 & - & - \\
\hline 1953 & 10.11 & 7.01 & - & - \\
\hline 1954 & 8.33 & 6.53 & - & - \\
\hline 1955 & -6.87 & -11.37 & - & - \\
\hline 1956 & -1.87 & -6.77 & - & - \\
\hline 1957 & -1.23 & -4.93 & - & - \\
\hline 1958 & 9.31 & 6.31 & - & - \\
\hline 1959 & 8.00 & 7.40 & $513,068,294$ & $68,999,581$ \\
\hline 1960 & 0.90 & -0.10 & - & - \\
\hline 1961 & 0.61 & -2.79 & - & - \\
\hline 1962 & 10.01 & 5.71 & - & - \\
\hline 1963 & 8.86 & 6.86 & - & - \\
\hline
\end{tabular}


APPENDIX TABLE 1B - continued

\begin{tabular}{|c|c|c|c|c|}
\hline \multirow[b]{2}{*}{ Year } & \multicolumn{2}{|c|}{$\begin{array}{l}\text { Annual Returns } \\
(\%)\end{array}$} & \multicolumn{2}{|c|}{$\begin{array}{l}\text { Total Par Value of Debentures } \\
\qquad(\mathfrak{E})\end{array}$} \\
\hline & Nominal & Real & Nominal & Real \\
\hline 1964 & 3.03 & -0.27 & - & - \\
\hline 1965 & 2.75 & -2.05 & - & - \\
\hline 1966 & 1.86 & -2.04 & - & - \\
\hline 1967 & 5.20 & 2.70 & - & - \\
\hline 1968 & -0.22 & -4.92 & - & - \\
\hline 1969 & -5.79 & -11.19 & $1,685,992,301$ & $158,143,979$ \\
\hline 1970 & 7.16 & 0.76 & - & - \\
\hline 1971 & 15.92 & 6.52 & - & - \\
\hline 1972 & 6.98 & -0.12 & - & - \\
\hline 1973 & -3.06 & -12.26 & - & - \\
\hline 1974 & -10.71 & -26.71 & - & - \\
\hline 1975 & 18.31 & -5.89 & - & - \\
\hline 1976 & 15.37 & -1.13 & - & - \\
\hline 1977 & 28.59 & 12.79 & - & - \\
\hline 1978 & 10.17 & 1.87 & - & - \\
\hline 1979 & 9.55 & -3.85 & $1,677,207,865$ & $40,005,883$ \\
\hline 1980 & 10.49 & -7.51 & - & - \\
\hline 1981 & 6.09 & -5.81 & - & - \\
\hline 1982 & 27.28 & 18.68 & - & - \\
\hline 1983 & 14.89 & 10.29 & - & - \\
\hline 1984 & 10.95 & 5.95 & - & - \\
\hline 1985 & 11.98 & 5.88 & - & - \\
\hline 1986 & 10.54 & 7.14 & - & - \\
\hline 1987 & 13.69 & 9.49 & - & - \\
\hline 1988 & 8.95 & 4.05 & - & - \\
\hline 1989 & 6.37 & -1.43 & $3,102,269,359$ & $33,739,922$ \\
\hline 1990 & 7.62 & -1.88 & - & - \\
\hline 1991 & 17.20 & 11.30 & - & - \\
\hline 1992 & 13.71 & 10.01 & - & - \\
\hline 1993 & 21.05 & 19.45 & - & - \\
\hline 1994 & 0.96 & -1.44 & - & - \\
\hline 1995 & 11.96 & 8.46 & - & - \\
\hline 1996 & 11.27 & 8.87 & - & - \\
\hline 1997 & 19.09 & 15.99 & - & - \\
\hline 1998 & 18.60 & 15.20 & - & - \\
\hline 1999 & 7.97 & 6.47 & $5,622,203,877$ & $41,821,041$ \\
\hline 2000 & 7.04 & 4.04 & - & - \\
\hline 2001 & 4.65 & 2.85 & - & - \\
\hline 2002 & 7.21 & 5.51 & - & - \\
\hline
\end{tabular}

Notes: See the notes in Appendix Table 1A.

Sources: See the sources in Appendix Table 1A.

\section{REFERENCES}

Acheson, Graeme G., Charles R. Hickson, John D. Turner, and Qing Ye. "Rule Britannia! British Stock Market Returns, 1825-1870.” The Journal of Economic History 69, no. 4 (2009): 1107-37.

Anon. "The Availability of the Floating Charge as a Security Device in the United States." Columbia Law Review 28, no. 3 (1928): 360-66. . "The U.K. Corporate Bond Market." Bank of England Quarterly Bulletin (March 1981): 54-58. 
Armour, John. "The Chequered History of the Floating Charge." Griffith Law Review 13, no. 1 (2004): 25-56.

"Should We Redistribute in Insolvency?" Centre for Business Research, Mimeo, Cambridge University, 2006.

Armour, John, Brian R. Cheffins, and David A. Skeel. "Corporate Ownership Structure and the Evolution of Bankruptcy Law: Lessons from the United Kingdom." Vanderbilt Law Review 55, no. 6 (2002): 1699-785.

Armour, John, Simon Deakin, Prabirjit Sarkar, Matthias Siems, and Ajit Singh. "Shareholder Protection and Stock Market Development: An Empirical Test of the Legal Origins Hypothesis." Journal of Empirical Legal Studies 6, no. 2 (2009): 343-80.

Baker, Mae, and Michael Collins. "Financial Crises and Structural Change in English Commercial Bank Assets, 1860-1913." Explorations in Economic History 36, no. 4 (1999): 428-44.

Bank for International Settlements. BIS Quarterly Review: International Banking and Financial Market Developments. Basel: BIS, 2011.

Beck, Thorsten, Asli Demirgüç-Kunt, and Ross Levine. "Law and Finance: Why Does Legal Origin Matter?” Journal of Comparative Economics 31, no. 4 (2003): 65375.

Biais, Bruno, and Richard C. Green. "The Microstructure of the Bond Market in the Twentieth Century." IDEI Working Paper No. 482, Toulouse, August 2007.

Bordo, Michael D., and Peter L Rousseau. "Legal-Political Factors and the Historical Evolution of the Finance-Growth Link." European Review of Economic History 10, no. 3 (2006): 421-44.

Boyd, John H., Ross Levine, and Bruce D. Smith. "The Impact of Inflation on Financial Sector Performance.” Journal of Monetary Economics 47, no. 2 (2001): 221-48.

Braggion, Fabio, and Steven Ongena. "A Century of Firm-Bank Relationships: Why the Transition to Multiple Banking?" Tilburg University CentER Working Paper, Tilburg, 2011.

Brierly, Peter, and Gertjan Vlieghe. "Corporate Workouts, the London Approach and Financial Stability.” Financial Stability Review 7 (November 1999): 168-83.

Burdett's Official Intelligence, 1882-1898.

Campbell, Gareth, and John D. Turner. "Substitutes for Legal Protection: Corporate Governance and Dividends in Victorian Britain." Economic History Review 64, no. 2 (2011): 571-97.

Capie, Forrest, and Michael Collins. Have the Banks Failed British Industry? London: IEA, 1992.

Chambers, David. "Going Public in Interwar Britain.” Financial History Review 17, no. 1 (2010): 51-71.

Cheffins, Brian R. "Does Law Matter? The Separation of Ownership and Control in the United Kingdom." Journal of Legal Studies 30, no. 2 (2001): 459-84.

Cheffins, Brian R., Steven A. Bank, and Harwell Wells. "Questioning Law and Finance: U.S. Stock Market Development, 1930-1970." University of Cambridge Legal Studies Research Paper Series 14/2012, Cambridge, 2012.

Collins, Michael. "English Bank Lending and the Financial Crisis of the 1870s." Business History 32, no. 2 (1990): 198-224.

Banks and Industrial Finance in Britain, 1800-1939. Cambridge: Cambridge University Press, 1991. 
Collins, Michael, and Mae Baker. "Sectoral Differences in English Bank Asset Structures and the Impact of Mergers, 1860-1913." Business History 43, no. 4 (2001): 1-28.

Commercial Banks and Industrial Finance in England and Wales, 1860 1913. Oxford: Oxford University Press, 2003.

Cottrell, Philip L. Industrial Finance, 1830-1914. London: Methuen, 1980.

Course of the Exchange, 1860-1871.

Curtis, G. F. "The Theory of the Floating Charge." University of Toronto Law Journal 4, no. 1 (1941): 131-50.

Daunton, Martin. Just Taxes: The Politics of Taxation in Britain, 1914-1979. Cambridge: Cambridge University Press, 2002.

Dimson, Elroy, Paul Marsh, and Mike Staunton. Triumph of the Optimists: 101 Years of Global Investment Returns. Princeton, NJ: Princeton University Press, 2002.

. Credit Suisse Global Investment Sourcebook 2010. Zurich: Credit Suisse, 2011.

Djankov, Simeon, Oliver Hart, Caralee McLeish, and Andrei Shleifer. "Debt Enforcement Around the World." Journal of Political Economy 116, no. 6 (2008): 1105-49.

Djankov, Simeon, Caralee McLeish, and Andrei Shleifer. "Private Credit in 129 Countries." Journal of Financial Economics 84, no. 2 (2007): 299-329.

Edelstein, Michael. "The Realized Rates of Return of U.K. Home and Overseas Portfolio Investments in the Age of High Imperialism." Explorations in Economic History 13, no. 3 (1976): 283-330.

. "The Realized Rate of Return to 703 U.K. Home and Foreign Equity, Preference and Debenture Securities, 1870-1913: Data Sources, Description and Excel Instructions." Mimeo, City University of New York, New York, 2010.

Essex-Crosby, A. "Joint Stock Companies in Great Britain, 1880-1935.” M. Comm. Thesis, University of London, 1938.

Finnie, David. Finding Capital for Business. London: Sir Issac Pitman \& Sons, 1931.

Fohlin, Caroline. "Does Civil Law Tradition and Universal Banking Crowd Out Securities Markets? Pre-World War I Germany as Counter-Example." Enterprise and Society 8, no. 3 (2007): 602-41.

Franks, Julian, Colin Mayer, and Stefano Rossi. "Ownership: Evolution and Regulation." Review of Financial Studies 22, no. 10 (2009): 4009-56.

Glyn, Andrew. "The Stock Market Valuation of British Companies and the Cost of Capital, 1955-69." Oxford Economic Papers 25, no. 2 (1973): 213-40.

Grant, A. T. K. A Study of the Capital Market in Britain from 1919-1936. 2nd edition. London: Frank Cass \& Co., 1967.

Grossman, Richard S. "New Indices of British Equity Prices, 1870-1913.” The Journal of Economic History 62, no. 1 (2002): 121-46.

Guinnane, Timothy, Ron Harris, Naomi R. Lamoreaux, and Jean-Laurent Rosenthal. "Putting the Corporation in Its Place." Enterprise and Society 8, no. 3 (2007): $687-729$.

Huybens, Elisabeth, and Bruce D. Smith. "Inflation, Financial Markets, and Long-Run Real Activity.” Journal of Monetary Economics 43, no. 2 (1999): 283-315.

Investor's Monthly Manual, 1864-1929.

Jefferis, Richard H. "The High-Yield Debt Market, 1980-1990.” Federal Reserve Bank of Cleveland Economic Commentary 26 (April 1990): 1-6.

Jefferys, J. B. Business Organisation in Great Britain, 1856-1914. New York: Arno Press, 1977. 
Kemsley, Deen, and Doron Nissim. "Valuation of the Debt Tax Shield." Journal of Finance 57, no. 5 (2002): 2045-73.

Kennedy, William P. Industrial Structure, Capital Markets, and the Origins of British Economic Decline. Cambridge: Cambridge University Press, 1987.

Lamoreaux, Naomi R., and Jean-Laurent Rosenthal. "Legal Regime and Contractual Flexibility: A Comparison of Business's Organizational Choices in France and the United States During the Era of Industrialization." American Law and Economics Review 7, no. 1 (2005): 28-61.

La Porta, Rafael, Florencio Lopez-De-Silanes, and Andrei Shleifer. "The Economic Consequences of Legal Origins." Journal of Economic Literature 46, no. 2 (2008): 285-332.

La Porta, Rafael, Florencio Lopez-De-Silanes, Andrei Shleifer, and Robert W. Vishny. "Legal Determinants of External Finance.” Journal of Finance 52, no. 3 (1997): $1131-50$. 55 .

."Law and Finance." Journal of Political Economy 106, no. 6 (1998): 1113

. "Investor Protection and Corporate Governance." Journal of Financial Economics 58, no. 1-2 (2000): 3-27.

Levine, Ross. "Law, Finance, and Economic Growth." Journal of Financial Intermediation 8, no. 1-2 (1999): 8-35.

Liew, Venus Khim-Sen, "Which Lag Length Selection Criteria Should We Employ?" Economics Bulletin 3, no. 33 (2004): 1-9.

London Stock Exchange, Historic Statistics Pre-2005. Available online at http://www.londonstockexchange.com/statistics/historic/stats-summarypre-2005/historic.htm, 2011.

Malmendier, Ulrike. "Law and Finance 'At the Origin'." Journal of Economic Literature 47, no. 4 (2009): 1076-108.

Maltby, Josephine, Janette Rutterford, David R. Green, Steven Ainscough, and Carien van Mourik. "The Evidence for 'Democratization' of Share Ownership in Great Britain in the Early Twentieth Century." In Men, Women, and Money: Perspectives on Gender, Wealth, and Investment, 1850-1930, edited by David R. Green, Alastair Owens, Josephine Maltby, and Janette Rutterford, 184-206. Oxford: Oxford University Press, 2011.

Manson, Edward. The Debentures and Debenture Stock of Trading and Other Companies. London: William Clowes and Sons, 1894.

Modigliani, Franco, and Merton H. Miller. "Corporate Income Taxes and the Cost of Capital: A Correction." American Economic Review 53, no. 3 (1963): 433-43.

Michie, Ranald C. The London Stock Exchange: A History. Oxford: Oxford University Press, 1999.

. "Gamblers, Fools, Victims, or Wizards? The British Investor in the Public Mind, 1850-1930." In Men, Women, and Money: Perspectives on Gender, Wealth, and Investment, 1850-1930, edited by David R. Green, Alastair Owens, Josephine Maltby and Janette Rutterford, 156-83. Oxford: Oxford University Press, 2011.

Morgan, E. V., and W. A. Thomas. The Stock Exchange: Its History and Functions. London: Elek Books, 1962.

Musacchio, Aldo. "Can Civil Law Countries Get Good Institutions? Lessons from the History of Creditor Rights and Bond Markets in Brazil." The Journal of Economic History 68, no. 1 (2008a): 80-108. 
. "Laws Versus Contracts: Legal Origins, Shareholder Protections, and Ownership Concentration in Brazil, 1890-1950." Business History Review 82, no. 3 (2008b): 445-73.

. Experiments in Financial Democracy: Corporate Governance and Financial Development in Brazil, 1882-1950. Cambridge: Cambridge University Press, 2009.

. "Law and Finance c.1900." NBER Working Paper No. 16216, Cambridge, MA, July 2010.

Nevin, Edward, and E. W. Davis. The London Clearing Banks. London: Elek Books, 1970.

O'Donoghue, Jim, Louise Goulding, and Grahame Allen. "Composite Price Index, 1750-2003." Economic Trends 604 (March 2004): 38-46.

Officer, Lawrence H. "What Was the U.K. GDP Then?" MeasuringWorth.Com, 2011.

Parliamentary Papers. Report of the Company Law Amendment Committee. London: HMSO, 1906.

Pennington, Robert R. “The Genesis of the Floating Charge.” Modern Law Review 23, no. 6 (1960): 630-46.

Perotti, Enrico, and Armin Schwienbacher. "The Political Origin of Pension Funding." Journal of Financial Intermediation 18, no. 3 (2009): 384-404.

Perotti, Enrico N., and Ernst-Ludwig von Thadden. "The Political Economy of Corporate Control and Labor Rents." Journal of Political Economy 114, no. 1 (2006): 145-74.

Rajan, Raghuram G., and Luigi Zingales. "The Great Reversals: The Politics of Financial Development in the Twentieth Century." Journal of Financial Economics 69, no. 1 (2003): 5-50.

Raynes, H. E. "The Place of Ordinary Stocks and Shares in the Investment of Life Assurance Funds." Journal of the Institute of Actuaries 64, no. 1 (1928): 21-50.

. "Equities and Fixed Interest Stocks During Twenty-Five Years." Journal of the Institute of Actuaries 64, no. 4 (1937): 397-418.

Register of Defunct Companies, 1979-2002.

Roe, Mark J. "Legal Origins and Modern Stock Markets." Harvard Law Review 120, no. 2 (2006): 460-527.

Roe, Mark J., and Jordan I. Siegel. "Finance and Politics: A Review Essay Based on Kenneth Dam's Analysis of Legal Traditions in the Law-Growth Nexus." Journal of Economic Literature 47, no. 3 (2009): 781-800.

. "Political Instability: Effects on Financial Development, Roots in the Severity of Economic Inequality." Journal of Comparative Economics 39, no. 3 (2011): 279-309.

Rutterford, Janette, David R. Green, Josephine Maltby, and Alastair Owens. "Who Comprised the Nation of Shareholders? Gender and Investment in Great Britain, c.1870-1935." Economic History Review 64, no. 1 (2011): 157-87.

Samuels, John M., and Francis M. Wilkes. Management of Company Finance. 2nd edition. London: Nelson, 1975.

Sarkar, Prabirjit, and Ajit Singh. "Law, Finance and Development: Further Analyses of Longitudinal Data." Cambridge Journal of Economics 34, no. 2 (2010): 32546.

Schinasi, Garry J., and R. Todd Smith. "Fixed-Income Markets in the United States, Europe, and Japan: Some Lessons for Emerging Markets." IMF Working Paper WP/98/177 (1998): 1-43. 
Scott, Peter. "Towards the 'Cult of Equity'? Insurance Companies and the Interwar Capital Market." Economic History Review 55, no. 1 (2002): 78-104.

Sefton, James, and Martin Weale. Reconciliation of National Income and Expenditure: Balanced Estimates for the United Kingdom, 1920-1990. Cambridge: Cambridge University Press, 1996.

Sheppard, David K. The Growth and Role of U.K. Financial Institutions, 1880-1962. London: Methuen, 1971.

Simonson, Paul F. The Debenture and Debenture Stock Holders' Legal Handbook. London: Effingham Wilson, 1920.

Smith, K. C., and G. F. Horne. An Index Number of Securities, 1867-1914. London: Royal Economic Society, 1934.

Statistical Abstract for the United Kingdom, 1871-1913.

Stock Exchange. Register of Defunct and Other Companies Removed from the Stock Exchange Official Year-book. East Grinstead: Thomas Skinner and Co., 1979.

Stock Exchange Daily Official List, 1930-2002.

Stock Exchange Official Intelligence, 1899-1933.

Stock Exchange Yearbook, 1876-2002.

Thomas, W. A. The Finance of British Industry, 1918-1976. London: Methuen \& Co., 1978.

Wadsworth, J. E. The Banks and the Monetary System in the UK, 1959-1971. London: Methuen \& Co., 1973.

Watson, Katherine. "Banks and Industrial Finance: The Experience of Brewers, 1880 1913." Economic History Review 49, no. 1 (1996): 58-81.

Williamson, Samuel H. "Seven Ways to Compute the Relative Value of a U.S. Dollar Amount, 1774 to Present." MeasuringWorth.Com, 2011.

Wilson Committee. Report of Committee to Review the Functioning of Financial Institutions. London: HMSO, 1980. 